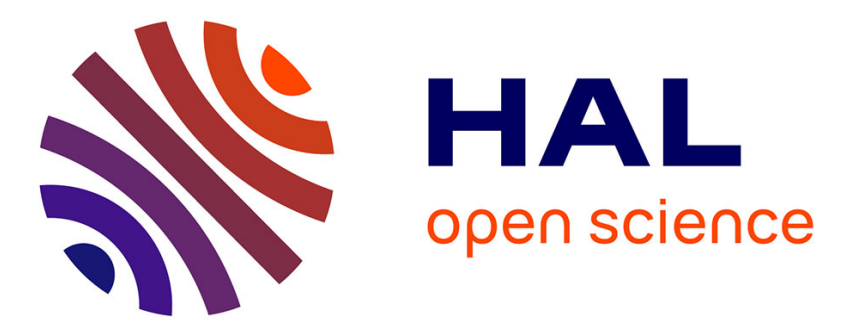

\title{
Genetic insights into recolonization processes of Mediterranean octocorals
}

D. Aurelle, J. Tariel, F. Zuberer, A. Haguenauer, C. Ribout, M. Masmoudi, H. Kara, L. Chaoui, J. Garrabou, J.-B. Ledoux, et al.

\section{- To cite this version:}

D. Aurelle, J. Tariel, F. Zuberer, A. Haguenauer, C. Ribout, et al.. Genetic insights into recolonization processes of Mediterranean octocorals. Marine Biology, 2020, 167 (6), pp.73. 10.1007/s00227-02003684-z . hal-02569518

\section{HAL Id: hal-02569518 \\ https://hal.science/hal-02569518}

Submitted on 11 May 2020

HAL is a multi-disciplinary open access archive for the deposit and dissemination of scientific research documents, whether they are published or not. The documents may come from teaching and research institutions in France or abroad, or from public or private research centers.
L'archive ouverte pluridisciplinaire HAL, est destinée au dépôt et à la diffusion de documents scientifiques de niveau recherche, publiés ou non, émanant des établissements d'enseignement et de recherche français ou étrangers, des laboratoires publics ou privés. 
1 Genetic insights into recolonization processes of Mediterranean octocorals

3 Authors : D. Aurelle ${ }^{1,2,3}$, J. Tariel ${ }^{3,4}$, F. Zuberer ${ }^{5,6}$, A. Haguenauer ${ }^{3,6}$, C. Ribout ${ }^{3,7}$, M.

4 Masmoudi $^{3,8}$, H. Kara ${ }^{8}$, L. Chaoui ${ }^{8}$, J. Garrabou ${ }^{1,9}$, J.-B. Ledoux ${ }^{9,10}$, M. C. Gambi ${ }^{11}$

51 Aix Marseille Univ, Université de Toulon, CNRS, IRD, MIO, Marseille, France

62 Institut de Systématique, Evolution, Biodiversité (ISYEB), Muséum national d'Histoire naturelle,

7 CNRS, Sorbonne Université, EPHE, 57 rue Cuvier, 75005 Paris, France

83 Aix Marseille Univ, Avignon Université, CNRS, IRD, IMBE, Marseille, France

94 Université Claude Bernard Lyon 1, CNRS UMR 5023, ENTPE, Laboratoire d’Ecologie des

10 Hydrosystèmes Naturels et Anthropisés, F-69622 Villeurbanne, France

115 Aix Marseille Univ, CNRS, IRD, OSU PYTHEAS, Marseille, France

126 EPHE, PSL Research University, UPVD, CNRS, USR 3278 CRIOBE, Moorea Polynésie, France

137 Centre d'Etudes Biologiques de Chizé (CEBC), UMR 7372 CNRS- La Rochelle Université, F-

1479360 Villiers-en-bois,France

158 Université d’Annaba Badji Mokhtar, Laboratoire Bioressources marines, Annaba, Algérie.

169 Institut de Ciències del Mar CSIC, Passeig Maritim de la Barceloneta 37-49, E-08003, Barcelona, 17 Spain

1810 CIIMAR/CIMAR, Centro Interdisciplinar de Investigação Marinha e Ambiental, Universidade 19 do Porto, Porto, Portugal

2011 Stazioner Zoologica Anton Dohrn. Dpt. Integrative Marine Ecology, Villa Comunale 80121,

21 Napoli, Italy

23 Corresponding author: Didier Aurelle didier.aurelle@univ-amu.fr

24 Keywords: octocorals, population genetics, colonization, artificial substrates, microsatellites 


\section{Abstract}

26 Marine ecosystems are strongly impacted by the consequences of human activities, such as habitat

27 destruction or artificialization, and climate change. In the Mediterranean Sea, sessile benthic

28 species, and particularly octocorals, have been affected by mass mortality events linked with

29 positive thermal anomalies. The future survival of octocoral populations impacted by global change

30 will depend on their recolonization abilities facing local extirpation or important modification of

31 their habitat. We studied these processes in Mediterranean octocorals in two situations: the

32 colonization of artificial substrates (wrecks) by the red gorgonian Paramuricea clavata, and the

33 recolonization following mortality events in the yellow gorgonian Eunicella cavolini. With

34 microsatellite markers (seven for P. clavata, five for E. cavolini), we analyzed the genetic diversity

35 of populations on artificial substrates and their differentiation from other neighboring populations.

36 For $P$. clavata the populations on artificial substrates were not or lowly differentiated from the

37 closest populations (1.3 to $1.6 \mathrm{~km}$ ) on natural substrates, and showed similar levels of genetic

38 diversity. Artificial substrates can then be considered as an interesting substitute for natural

39 substrates for this species. For E. cavolini we did not detect any variation in diversity nor

40 relatedness following recuperation after mortality events. In both cases our results suggest the input

41 from different populations in the recolonization process, which helps in maintaining the genetic

42 diversity. These results are useful for the management of these species and of associated

43 ecosystems. 


\section{Introduction}

46 Marine biodiversity is increasingly impacted by global and local pressures such as climate change,

47 overfishing, introduction of invasive species, habitat destruction and pollution (Boudouresque et al.

48 2017; Gattuso et al. 2018). The combination of these pressures questions the possibility of evolution

49 and persistence of numerous marine species. Whereas the global impact of human activities on

50 biodiversity is still increasing, different solutions (from reduction of greenhouse gas concentrations

51 to manipulation of ecological adaptation and habitat restoration) are explored to mitigate this impact

52 in the marine realm, but with uncertainties regarding their efficiency and trade-offs (Gattuso et al.

53 2018).

54 Additionally, coastal areas face an expansion of artificial structures such as dikes, offshores

55 structures or even wrecks (Dafforn et al. 2015). The development of artificial structures can have contrasting consequences on marine biodiversity such as habitat loss or indirect modifications of the environment (Dafforn et al. 2015). Conversely, artificial structures can provide new habitats, and act as artificial reefs and connectivity nodes. Artificial structures can increase habitat complexity in seabed, complexity which has been impacted by activities such as trawling. Therefore, despite their negative effects, artificial structures can be considered as potential management tools in a context of

61 global change. The future of marine biodiversity will then depend on the evolutionary trajectories of populations in this changing and anthropized environment. These evolutionary trajectories include the possibility of genetic adaptation, acclimatization, gene flow, recolonization and range shift (Bell and Collins 2008). Global change can then be considered as a wide scale adaptive challenge for many species, submitting biodiversity to important and new selective pressures (Otto 2018).

66 In this context, population genetics can be used to study genetic connectivity, the possibility of

67 sustaining gene flow among habitats, including artificial ones, and the recolonization processes following disturbances. For example, a study of two scleractinian species, Pocillopora damicornis and Seriatopora hystrix, has shown a recolonization pattern mainly from neighbouring populations, 
70 but with occasional more distant sources (Starger et al. 2010). It is also important to consider the

71 consequences of recolonization on genetic diversity, for example through founder effects. A

72 founder effect will lead to changes in allele frequencies between source and sink populations, and to

73 a reduction in genetic diversity (Allendorf et al. 2017). Nevertheless, this is not always the case. For

74 instance, in the gastropod Nucella lapillus, no significant genetic effect of local extinction and

75 recolonization was detected, despite a priori low dispersal abilities (Colson and Hughes 2004).

76 Depending on the ecology of the species (e.g. age at sexual maturity), the strength of founder

77 effects during recolonization will vary ranging from drastic reduction of intra-population genetic

78 diversity and an increase in genetic differentiation between populations, to a lack of effect

79 (Austerlitz et al. 2000). The type of habitat (natural / artificial) can also impact the level of genetic

80 diversity, as observed in the gastropod Patella caerulea where populations on urban structures

81 showed less genetic diversity than populations on natural rocky habitats (Fauvelot et al. 2009).

83 The Mediterranean Sea, with a combination of an important species diversity and strong human

84 pressures including climate change, is a hotspot of biodiversity (Coll et al. 2010, 2012; Cramer et al.

85 2018). Mass mortality events induced by thermal anomalies have been observed in the last decades

86 in the northern Mediterranean (Garrabou et al. 2009; Verdura et al. 2019). These mortality events

87 have impacted several sessile groups of species such as sponges and octocorals. For a given species,

88 the impact was different among regions and depths (Garrabou et al. 2009). Global (e.g. warming) or

89 local (e.g. habitat destruction) pressures can lead to population decline or extinction (extirpation).

90 This combination of human pressures raises the question of the survival of octocoral populations

91 facing global change, which is linked to their adaptive potential. For example, octocoral populations

92 from different depths show in some cases different thermotolerance levels, and this diversity could

93 be important for adaptive evolution (Haguenauer et al. 2013; Ledoux et al. 2015; Pivotto et al.

94 2015). At a metapopulation level, population decline or extirpation can be compensated by

95 migration from other populations, which can have positive demographic and genetic effects (Ronce 
96 2007). In this context, the aforementioned increasing availability of artificial substrates should be

97 considered, as artificial structures can allow the development of new local populations and modify

98 the connectivity network. Studying the recolonization abilities of octocorals at a genetic level, on

99 natural and artificial substrates, is therefore of paramount importance to better understand their

100 future evolution and conservation.

101 Population genetic studies of Mediterranean octocorals have regularly evidenced a significant

102 genetic differentiation at short distance, from a few tens to hundred meters. This was the case, at

103 different levels, for the red coral Corallium rubrum (e.g. Costantini et al. 2007; Ledoux et al. 2010a,

104 2010b; Pratlong et al. 2018), the red gorgonian Paramuricea clavata (Mokhtar-Jamai et al. 2011;

105 Arizmendi-Mejía et al. 2015), and the yellow gorgonian Eunicella cavolini (Masmoudi et al. 2016;

106 Cánovas-Molina et al. 2018). This marked genetic structure could be the result of a combination of

107 reduced mean dispersal distance (Ledoux et al. 2010a), an important genetic drift, and of priority

108 effect (Orsini et al. 2013). Studying the genetic diversity of recently colonized or recolonized sites

109 would then be interesting to better understand the processes shaping the genetic structure of these

110 species. For example a founder effect along with a priority effect could lead to a persistent genetic

111 differentiation at unexpected short distance. Genetic data on recolonization are scarce in

112 Mediterranean octocorals. Arizmendi-Mejía et al. (2015) observed that a recently established

113 population of $P$. clavata in Ibiza island (Balearic Islands, East Spain), probably originated from

114 several source populations, which can explain its relatively high levels of genetic diversity

115 compared to the other investigated populations. In the same species, a lack of marked founder effect

116 was also suggested during recolonization process following last glacial maximum (Ledoux et al.

117 2018). Focusing on Eunicella cavolini, Cánovas-Molina et al. (2018) suggested that colonies

118 established on artificial reefs in the area of Marseille (South-East France) could come from different 119 populations.

120 In the present study we propose to extend our knowledge regarding colonization processes in these

121 species with two case studies: the colonization of two artificial substrates (wrecks) by P. clavata, 
122 and the recolonization of a natural substrate after a strong mortality event in E. cavolini. In both

123 cases we aim to estimate the contribution of neighboring populations to the newly (re)colonized

124 population. We also test if the dynamics of these colonizations are associated with founder events

125 (i.e. a reduction in genetic diversity, or a differentiation of the new populations from neighbouring

126 ones). This study sheds new light on the origin of short distance genetic differentiation in

127 Mediterranean octocorals and should improve our understanding regarding the evolution of marine

128 biodiversity in changing and artificializing seascapes.

\section{Material and methods}

131 Sampling and population history:

132 All colonies were sampled by scuba diving. Regarding $P$. clavata, we sampled two populations

133 established on the ships « Donator » (DON) and « Le Grec » (GRE), both ships wrecked in 1945 in

134 the same area in southeastern France. Eight additional populations on natural substrates were

135 sampled, with increasing distance from the wrecks, up to the Marseilles area for the most distant

136 sites (up to $75 \mathrm{~km}$ by sea; Table 1 and Fig. 1). The distance with the closest population on natural

137 substrate (SAR) is around $1.3 \mathrm{~km}$ for GRE and $1.6 \mathrm{~km}$ for DON. The sample size for $P$. clavata

138 varied between 29 and 39 colonies. For E. cavolini, we focused on the sampling of four populations

139 around the island of Ischia (Tyrrhenian Sea, West Italia; Table 1 and Fig. 1) which experienced

140 strong mortality events: Sant'Angelo (SAN), Secca delle Formiche (SFV), and La Nave (LAN)

141 where mortality was documented in 2002, 2003, 2005 (except in LAN) and 2009 (Gambi et al.

142 2006, 2010; Garrabou et al., 2009; Cigliano and Gambi 2007; Gambi 2014), and La Grotta Azzurra

143 at Palinuro (GAZ, Salerno; 15-25 m depth), a semi-submerged cave where a strong mortality event

144 was registered in October 2008, with 77\% of dead colonies at $15 \mathrm{~m}$ depth (Gambi et al. 2010), and a

145 slight recovery of the population already observed in July 2011 (Gambi and Barbieri 2012). We also

146 sampled two populations that, to our knowledge, did not experience any recent mortality event: the

147 Nisida island (NISB, Gulf of Naples), and the Secchitello bank (UST, Ustica island, North Sicily) 
148 where E. cavolini is distributed relatively deep (below $30 \mathrm{~m}$ depth). In the sites affected by

149 mortality events we likely sampled both young E. cavolini individuals and residual individuals

150 which recruited before the mortality events. These E. cavolini populations were sampled in June

151 and July 2013. Therefore we sampled from 4 to 11 years after mortality events for impacted

152 populations. Regarding the evolution of density and the size structure of E. cavolini at the site GAZ

153 after the 2008 mortality event (Gambi and Barbieri 2012), samples mainly come from colonies

154 recruited after this event. The sample size for E. cavolini varied between 14 and 38 colonies. For

155 both species, 3-4 cm fragments from an apical branch were sampled from each colony, and stored in 156 ethanol $95 \%$ at $-20^{\circ} \mathrm{C}$ before DNA extraction.

158 Microsatellite markers:

159 DNA extraction was performed according to Mokhtar-Jamai et al. (2011), Ribout and Carpentieri 160 (2013), and Masmoudi et al. (2016) depending on the samples. The P. clavata colonies have been 161 genotyped with the loci Para9, Para10, Para12, Para14, Para17, Pard and Para2-37 as in Molecular

162 Ecology Resources Primer Development Consortium et al. (2010) and Mokhtar-Jamai et al. (2011).

163 Data from GAB, PTV, MTM, RIO, RIS and IMP were available from Mokhtar-Jamai et al. (2011).

164 The E. cavolini colonies have been genotyped with the loci S14, C21, C30, C40 and Mic56

165 following Masmoudi et al. (2016).

Genetic diversity:

168 We identified repeated multilocus genotypes (MLGs) and we computed the probability of 169 occurrence of multiple MLGs under sexual reproduction with the poppr 2.8.3 R package (Kamvar et 170 al. 2014, 2015). For all following analyses we kept one representative of each MLG. Observed and 171 expected heterozygosities were computed with the Genetix 4.05 software (Belkhir et al. 1999).

172 Allelic richness was estimated with a rarefaction procedure with the ADZE software (Szpiech et al. 173 2008), and by excluding for each species the sample with the lowest number of colonies. 
175 Genetic structure within and among populations:

176 Departures from panmixia were tested with the Genepop 4.5.1 software with an exact test and with

177 heterozygote deficiency as an alternative hypothesis (Rousset 2008). The level of relatedness within 178 populations was computed with the estimator of Wang (2002) implemented in the COANCESTRY 179 software (Wang 2011). To compare the levels of relatedness between populations we used the 180 bootstrap approach of COANCESTRY with 1000 resamplings. The level of genetic differentiation 181 was estimated with the $F_{\text {ST }}$ estimate of Weir and Cockerham (1984). Previous studies did not detect 182 a strong impact of null alleles for the loci analysed here in each species (Mokhtar-Jamaï et al., 2011; 183 Masmoudi et al., 2016). Nevertheless, regarding the $F_{\text {IS }}$ values observed here and in previous 184 studies, and the missing data observed in some populations (see results), we also estimated $\mathrm{F}_{\mathrm{ST}}$ with 185 a correction for null allele from the FreeNA software (Chapuis and Estoup 2007). Genic 186 differentiation between populations was tested with the exact test procedure implemented in 187 Genepop. To estimate the relative differentiation of each population, we computed the populationspecific $F_{\mathrm{ST}}$ in GESTE (Foll and Gaggiotti 2006; Gaggiotti and Foll 2010).

189 The genetic differences among individuals was visualized thanks to a Principal Component 190 Analysis (PCA; function dudi.pca) with the Adegenet R package (Jombart 2008). We made an 191 individual clustering analysis with the STRUCTURE software (Pritchard et al. 2000) with $10^{6}$ 192 iterations for the burn-in and $10^{6}$ iterations for the main analysis, 10 replicates for each $\mathrm{K}$, and by 193 testing $\mathrm{K}=1$ to $\mathrm{K}=6$ in the two species. We used an admixture model with correlated allele 194 frequencies. The results were visualized with the POPHELPER website (Francis 2017; 195 http://pophelper.com/).

196 To infer the genetic origin of populations installed on artificial substrates (DON and GRE for 197 P. clavata), and of new recruits after a complete recolonization (GAZ for E. cavolini), we used the 198 GENECLASS2 software (Piry et al. 2004) with the option to infer individual assignment, by using 199 all other populations as references. We used the Rannala and Mountain (1997) criterion, and the 
membership probability was computed according to Paetkau et al. (2004), with 1000 simulated

201 individuals, and a type I error of 0.01.

202

\section{Results}

204 Occurences of repeated MLGs:

205 For P. clavata, five pairs of repeated MLGs were observed: two in the GRE population, one in 206 MTM, one in DON, one in RIS. The corresponding probability of occurrence of repeated genotypes 207 under sexual reproduction (psex) ranged from $7 \cdot 10^{-9}$ to $2.10^{-5}$. For E. cavolini, three MLGs were 208 detected more than once, all in the NISB population: one was repeated nine times (psex $=0.010$ ), 209 another one five times (psex $=0.014)$ and another one two times (psex $=0.014)$. The overall 210 frequency of missing genotypes was around $17 \%$ for E. cavolini (mainly concentrated in the SFV 211 and LAN populations), and 10\% for P. clavata (mainly in PQL).

213 Genetic diversity and structure within populations:

214 When considering rarefied allelic richness for P. clavata, the DON and GRE wreck populations had 215 an $\operatorname{Ar}(29)$ of 7.6 and 7.7 respectively, similar to the value observed for the neighbouring population 216 SAR (7.5; Table 1). The expected heterozygosity for DON and GRE was 0.62 and 0.65

217 respectively, whereas it was 0.61 for SAR, the lowest value found here. Regarding E. cavolini, the 218 rarefied allelic richness for GAZ (recolonized population; sample size $\mathrm{N}=32$ ) was the second 219 highest value after the LAN population $(\mathrm{N}=25)$, with $\operatorname{Ar}(14)=4.9$ and 5.4 respectively. The same 220 trend was observed when considering expected heterozygosity, with values of 0.70 and 0.71 for 221 GAZ and LAN respectively. NISB and UST, for which we have no indication of mortality events, 222 showed the lowest allelic richness and expected heterozygosity values, but with small sample sizes 223 in both cases (Table 1).

224 For $P$. clavata, all samples showed a significant deviation from panmixia, with heterozygote 225 deficiencies varying from 0.06 (PTV and GRE) to 0.16 (PQL). For E. cavolini, three samples over 
226 six showed a significant deviation from panmixia, and heterozygote deficiencies varied from 0.01

227 (SFV) to 0.20 (SAN).

228 Regarding relatedness levels for P. clavata, the PTV and MTM populations showed higher mean

229 relatedness than most other populations, whereas GAB, PQL and RIO tended to have lower mean

230 relatedness than other populations (Table 2). There was no clear tendency for the wreck populations

231 DON and GRE. For E. cavolini, NISB and SFV showed higher mean relatedness than other

232 populations.

234 Genetic differentiation and origin of new recruits:

235 Regarding population differentiation, the global $\mathrm{F}_{\mathrm{ST}}$ estimate was 0.04 for $P$. clavata, and 0.08 for

236 E. cavolini. For both species, all pairwise differentiation tests were significant, apart from the 237 comparison between GRE and SAR for P. clavata, two sites separated by $1.3 \mathrm{~km}$ (Table 3). For

238 P. clavata, the differentiation between DON and SAR was low (uncorrected pairwise $\mathrm{F}_{\mathrm{ST}}=0.02$;

239 corrected pairwise $\mathrm{F}_{\mathrm{ST}}=0.03$; spatial distance: $1.6 \mathrm{~km}$ ) but significant. For E. cavolini and focusing

240 on the recolonized GAZ population, the lowest differentiation was observed with the LAN

241 population $\left(\mathrm{F}_{\mathrm{ST}}=0.08\right.$, for corrected and uncorrected estimates; distance $\left.140 \mathrm{~km}\right)$. The mean

242 pairwise $\mathrm{F}_{\mathrm{ST}}$ for the comparison involving GAZ was 0.1 and 0.07 for the uncorrected and corrected

243 estimates respectively. Accordingly, GAZ was then slightly more differentiated or at the same level

244 of differentiation than the other populations, except UST (range $0.04-0.11$ and $0.02-0.12$ for the

245 uncorrected and corrected estimates respectively).

246 Local $\mathrm{F}_{\mathrm{ST}}$ are presented in Table 4. For $P$. clavata, the PQL population displayed a higher local $\mathrm{F}_{\mathrm{ST}}$

247 than other populations, and the corresponding 95\% confidence interval did not overlap with those of

248 other populations. For E. cavolini, the highest local $\mathrm{F}_{\mathrm{ST}}$ was observed for NISB, but with a 95\%

249 confidence interval overlapping with those of other populations. None of the (re)colonized

250 populations showed significantly different values.

251 The PCA analysis of $P$. clavata did not show any clear structure pattern, with only a few individuals 
252 from IMP and RIS separated from the other ones on axes 1 and 2 (Fig. 2). For E. cavolini, the main

253 pattern was a distinction of GAZ and UST samples on axes 1 and 2 respectively. The individuals of

254 these two populations were genetically diverse as shown by their quite wide distribution on the 255 PCA axes.

256 The results of the individual clustering are presented in Fig. 3. For P. clavata, we present the results 257 for $\mathrm{K}=2$ to $\mathrm{K}=5$ since there was no informative distinction above this value. At $\mathrm{K}=2$, one can 258 observe a gradient between two clusters, a major one around Marseille (RIO, RIS, IMP), and a

259 minor one increasing in frequency in other populations. At $\mathrm{K}=3, \mathrm{GAB}, \mathrm{MTM}$ and PTV are

260 separated from the rest. At $K=5$, we also observe a slight distinction of two populations: MTM and 261 RIS. The wreck populations DON and GRE appear related to the SAR population. In all cases, the 262 separation among clusters was not complete. For $E$. cavolini, we present the results for $\mathrm{K}=2$ to $\mathrm{K}=$ 263 4, there was no informative distinction above this value. GAZ and UST are separated from other 264 populations at $\mathrm{K}=2$ while GAZ and UST are separated at $\mathrm{K}=3$. At $\mathrm{K}=4$ there is a distinction of 265 GAZ from other populations which are almost equally admixed among the three other clusters.

266 Nevertheless some individuals in GAZ seem more related to other populations than to the blue 267 cluster dominant in this population.

268 The results of assignment analyses are presented in supplementary Table 1 . For P. clavata, if we 269 arbitrarily consider a threshold of 0.95 for membership probabilities, three over 33 individuals of 270 DON could be related to SAR, six to PQL, three to RIO and one to IMP (this individual also 271 showed high probability for RIO). For GRE, three over 33 individuals could be related to SAR, and 272 seven over 33 to PQL. For E. cavolini, eight individuals over 32 displayed high membership 273 probability for the LAN population. In both cases several individuals displayed very low 274 membership probabilities for all the tested populations suggesting that they come from non sampled 275 sites. 
Spatial patterns of recolonization:

279 Our data allow discussing and comparing the dispersal and recolonization abilities of two

280 Mediterranean octocoral species. For P. clavata, we observed a genetic proximity between the

281 samples on the two wrecks DON and GRE, and the nearest population of natural substrate SAR.

282 The differentiation was very low (and even non significant for GRE) between these two populations

283 and SAR, $1.2 \mathrm{~km}$ apart. The longevity of P. clavata may reach 50 to 100 years, but their age is

284 difficult to estimate, for example due to variation in growth rate or breakage of some branches

285 (Linares et al. 2007). The age of the wrecks is known (more than 70 years), which sets an upper

286 limit to population age, but not the age of the sampled colonies. Some colonies sampled here could

287 then correspond to the first generation of founders, but also be descendants from these founders, or

288 descendants from more recent migrants. We can consider two non-mutually exclusive explanations

289 to the observed low differentiation among wrecks and surrounding populations. First, the initial

290 recruits came from the SAR population, with no or low enough founder effect that would have

291 induced initial differentiation. Second, gene flow from SAR after colonization could have

292 contributed to the genetic homogeneity of P. clavata at that scale. The lack of founder effect in

293 P. clavata was related to the late sexual maturity observed in this species (Coma et al. 1995;

294 Ledoux et al. 2018). Indeed, during the years following the foundation of a new population, the

295 expansion of the population is mainly due to new migrants and not to local reproduction. This

296 increases the effective population size until the first reproductive event buffering the founder effect

297 (Austerlitz et al. 2000). Even if significant, the low differentiation observed with other populations

298 than SAR points to the possible participation of these populations to the newly founded ones as

299 well. This is supported by assignment analysis indicating a contribution of PQL. In their study of a

300 recently founded population of $P$. clavata, Arizmendi-Mejía et al. (2015) identified multiple source

301 populations at distances ranging from $300 \mathrm{~m}$ to around $1 \mathrm{~km}$, which is similar to our results. The

302 larval duration of $P$. clavata has been estimated between 8 and $25 \mathrm{~d}$ in laboratory, which could

303 allow long distance dispersal (Linares et al. 2008). The assignment of three individuals to a 
population from Marseille can correspond to such long distance dispersal. Similarly, Padrón et al.

305 (2018) suggested that connectivity among coastal populations of $P$. clavata, possibly at tens of

306 kilometres, had contributed to their recovery after mortality events. Nevertheless, surface brooding

307 and larval behavior (negative phototaxis), and a short swimming phase may reduce the realized

308 dispersal in this species (Linares et al. 2008). In that case, we should consider that non sampled and

309 closer population(s) could have contributed to the mixed diversity of the wreck populations.

310 For E. cavolini, the colonies sampled in GAZ should be mainly new recruits following the 2008

311 mortality event. These recruits could correspond to local recruitment from the few remaining

312 colonies (Gambi and Barbieri 2012). There was no significant reduction in genetic diversity at that

313 site compared to other populations. This could mean that there was enough surrounding colonies to

314 sustain population recovery; for example one can note that the mortality event was less strong at

$31525 \mathrm{~m}$, and this would constitute a possible refugia. Additionally, recruits could have come from

316 different populations, as suggested by the genetic differences among individuals shown by

317 clustering and multivariate analyses. The origin of these foreign recruits in the GAZ population is

318 not clear based on our sampling. The assignment analysis suggested the possibility of LAN as

319 origin of the recruits in GAZ. LAN and GAZ are distant from around $140 \mathrm{~km}$ apart. This is at odd

320 with the local differentiation usually observed for this species (Cánovas-Molina et al. 2018). It

321 seems more probable that non-sampled populations, either genetically akin to LAN, or

322 corresponding to another genetic group, contributed to this signal of distant recolonization of GAZ.

323 In a preliminary study of the colonization of artificial reefs by E. cavolini, it was difficult to

324 precisely identify the population(s) of origin, but potential source populations could be distant by

325 two to three kilometres from these artificial structures (Cánovas-Molina et al. 2018). There is no

326 information on the larval biology of E. cavolini to further interpret these results. In the congeneric

327 species E. singularis, the settlement could be possible within $30 \mathrm{~h}$ (Weinberg 1979), but it would be

328 interesting to formally characterize the larval phase duration in E. cavolini.

329 In any case, the analysis of the colonized or recolonized populations in the two species studied here 
clearly indicate a mixed origin of the recruits. Recolonization from mixed origins, with sporadic distant input, has also been observed in hexacorals (Underwood et al. 2007; Starger et al. 2010). In the case of E. cavolini (GAZ), this was done in a relatively short time after mortality event

333 (mortality in 2008, sampling in 2013). Interestingly, Cupido et al. (2012) have observed an increase

334 in recruitment for $P$. clavata following mortality events, possibly because a greater space

335 availability. This could both limit the erosion of genetic diversity (see below), and allow gene flow

336 from other populations. From a methodological point of view, our results underline that studying

337 recolonization in Mediterranean octocorals should not only consider neighbouring populations, but 338 increase the sampling effort to distant populations.

Consequences on the genetic diversity of the populations:

We did not observe any impact of colonization or recolonization in the population diversity

342 of both species, nor with local $\mathrm{F}_{\mathrm{ST}}$ reflecting local drift. One can note that the expected

343 heterozygosities observed here for E. cavolini are higher than those previously reported by

344 Cánovas-Molina et al. (2018), and in the range of values obtained for populations from western

345 Mediterranean by Masmoudi et al. (2016), but in both cases with a microsatellite panel partly

346 different from the one used here.

347 As already mentioned, in the case of E. cavolini most other populations analysed here suffered from

348 mortality events which may have reduced their genetic diversity as well. Regarding P. clavata, the

349 levels of diversity observed here are in the lower range of those observed by Mokhtar-Jamai et al.

350 (2011) or Pérez-Portela et al. (2016), again with a partially different panel of microsatellite markers.

351 In the case of this species, depth has been shown to be positively correlated with genetic diversity

352 (Pilczynska et al. 2019). Even if the sampling scheme does not allow a precise study of this

353 question, a similar tendency was observed here with a mean expected heterozygosity of 0.67 for the

354 depth range 20 to $34 \mathrm{~m}$, and 0.69 for 40-41 m. In both species we observed significant heterozygote

355 deficits in most populations. This is in line with previous observations of departures from panmixia 
in Mediterranean gorgonians (e.g. Ledoux et al., 2010b; Mokhtar-Jamaï et al., 2011). These

357

358

359

360

361

362

363

364

departures have been explained by a combination of inbreeding and null alleles, and this does not seem linked with patterns of recolonization here.

The retention of genetic diversity and the lack of change in relatedness following recolonization can be the consequence of the mixed origin of the recruits. In E. cavolini, we did not observe any genetic effect of mortality events either. Nevertheless detecting such effects of mortality might require the comparison of more populations, and cohorts within populations, with more information on the date and impact of mortalities. In P. clavata, Pilczynska et al. (2016) did not detect any reduction in genetic diversity following mortality event as well. One can note that to have a genetic impact, any demographic shrinkage should be sustained over several generations (Allendorf 1986), whereas we consider here only a very low generation number. Additionally, partial mortality of colonies, long generation time (Lippé et al. 2006), late sexual maturity (Ledoux et al. 2018), and an increase in recruitment (Cupido et al. 2012) can buffer the genetic impact of bottlenecks or demographic accidents on populations. As shown here, in a metapopulation context, exchanges from more or less distant populations will also limit the genetic consequences of mortality events. These conclusions might be different on a longer term. The low survivorship success of the early stages, despite the high investment in the production of gametes in P. clavata (Coma et al. 1995), suggests that the species may have a low capacity to recover during large or frequent disturbances (Linares et al. 2008). More generally, if climate change induces strong and recurrent scale mortality events, this might lead to a reduction of larval recruitment of different species. This has been observed in scleractinians of the Great Barrier Reef after mass bleaching event (Hughes et al. 2019). In a context of population fragmentation, and anthropization of coastal areas, it is important to consider the role of artificial structures as potential substrates for settlement and to enhance biodiversity. In the Bay of Marseille, after 11 years of immersion, artificial reefs are already colonized by several octocoral species, such as E. cavolini, E. singularis and E. verrucosa (Guillemain et al., unpublished data). Our results show that the colonization of wrecks did not lead 
382 to a reduction of genetic diversity at a given range depth for P. clavata. Similarly, Ordóñez et al.

383 (2013) did not observe any significant difference in genetic diversity between populations of the

384 ascidian Microcosmus squamiger on artificial and natural substrates. Conversely a lower genetic

385 diversity was observed for the limpet Patella caerulea on artificial structures compared to natural

386 rocky substrates (Fauvelot et al. 2009). Such different results are probably linked to different

387 population dynamics, and to different interaction with the substrates according to the species. It will

388 then have different consequences on the role of these new substrates and associated populations in

389 the connectivity and genetic diversity of populations. In the case of octocorals, our results indicate

390 that artificial substrates provide good opportunities for the development of new populations, or the

391 extension of existing ones. Artificial substrates situated at a few kilometres from natural populations

392 can possibly be colonized and allow the development of new populations. It will be interesting to

393 extend connectivity studies in this context to test if these populations could have other impacts, such

394 as for example act as stepping stone to allow gene flow between previously isolated areas.

Factors driving short distance differentiation in Mediterranean octocorals

397 Genetic differentiation at short distance has been repeatedly observed in Mediterranean octocorals

398 (e.g. Costantini et al. 2007; Ledoux et al. 2010a; Mokhtar-Jamai et al. 2011; Cánovas-Molina et al.

399 2018). Several factors could contribute to such patterns. First a short mean dispersal distance has

400 been inferred from the analysis of local genetic structure, and from the observation of related

401 individuals at a very short distance in the red coral C. rubrum (Ledoux et al. 2010a). This may seem

402 at odd with the long larval survival (up to 42 days) estimated for this species in aquarium

403 (Martínez-Quintana et al. 2015). Also, the observation of a short-distance differentiation does not

404 preclude for the presence of sporadic more distant exchanges allowing gene flow at a larger

405 metapopulation scale. Such discrepancy between the spatial scale of genetic structure and the

406 duration of larval phase has been observed for example in the fish Elacatinus lori (D’Aloia et al.

407 2015), calling to more detailed study of factors driving connectivity. Second, genetic drift is the 
other important driver of genetic structure, and analyses of local genetic structure pointed to a

409 relatively low effective size in the red coral C. rubrum (Ledoux et al. 2010a). Finally, priority effect

410 at the genetic level can increase genetic differentiation, when the arrival of new recruits is limited

411 by the presence of already installed individuals (isolation by colonization; Orsini et al. 2013). Our

412 results, and previous ones (Arizmendi-Mejía et al. 2015), suggest that in a metapopulation context,

413 colonization or recolonization may not be limited by dispersal. Available habitat, either artificial or

414 natural, following mortality, seem to be easily recolonized, at least in a metapopulation context. A

415 temporal survey over several generations, or indirectly the comparison of different cohorts, would

416 allow estimating the strength of isolation following the founding of new populations.

\section{Perspectives:}

419 Our results show the possibility of successful (in terms of genetic diversity) colonization or 420 recolonization in Mediterranean gorgonians, including on artificial substrates. These data will be 421 useful for the spatial design of similar studies in these species. The use of a higher number of 422 markers such as SNPs could increase the power of assignment analyses as well (e.g. Glover et al. 423 2010; Benestan et al. 2015). Finally, it would be interesting to study the adaptation of these species 424 to new substrates with population genomics approaches (Manel et al. 2016). As this may be difficult 425 in a context of strong genetic structure (Pratlong et al. 2018), such results based on microsatellite 426 loci in different species will be useful to choose the best sampling scheme.

\section{Acknowledgements:}

429 The E. cavolini samples have been obtained thanks to an ASSEMBLE TA project granted to D. 430 Aurelle (grant agreement $n^{\circ}$ 227799), for an access to the Stazione Zoologica Anton Dohrn in 431 Naples. We thank Mr Fabio Barbieri, at the "Gambieri Marine Field Station", and the staff of the 432 Palinuro Sub Diving Center (Palinuro), the Ischia Diving Agency and the ANS diving (Ischia), and 433 the Alta Marea diving Center (Ustica) for support in collection of E. cavolini samples at Palinuro, 
434 Ischia and Ustica, respectively; Mr Marco Cannavacciuolo and the staff of the MEDA Unit

435 (RIMAR Dept Stazione Zoologica of Naples) for sampling colonies at the Nisida island (Naples).

436 The work of M. Masmoudi in France was supported by the Algerian - French collaboration

437 program Tassili n ${ }^{\circ}$ MDU853. This study has been funded by the French National Research

438 Agency (ANR) program Adacni (ANR n ANR 12 ADAP 0016; http://adacni.imbe.fr). The

439 project leading to this publication has received funding from European FEDER Fund under project

440 1166-39417. J.-B. Ledoux is funded by an assistant researcher contract framework of the RD Unit -

441 UID/Multi/04423/2019 - Interdisciplinary Centre of Marine and Environmental Research - financed

442 by the European Regional Development Fund (ERDF) through COMPETE2020 - Operational

443 Program for Competitiveness and Internationalisation (POCI) and national funds through

444 FCT/MCTES (PIDDAC). We thank Oscar Puebla and two anonymous reviewers who helped us

445 improve this article.

447 Conflict of Interest: The authors declare that they have no conflict of interest.

448 Sampling authorizations: all sampling have been performed with authorizations from the

449 corresponding local authorities.

451 Data availability:

452 All genotypes have been deposited in the Zenodo database under reference:

453 http://doi.org/10.5281/zenodo.3724056 
References:

Allendorf FW (1986) Genetic drift and the loss of alleles versus heterozygosity. Zoo Biol 5:181190

Allendorf FW, Luikart GH, Atken SN (2017) Conservation and the genetics of populations, $2^{\text {nd }}$ edition. John Wiley \& Sons.

Arizmendi-Mejía R, Linares C, Garrabou J, Antunes A, Ballesteros E, Cebrian E, Díaz D, Ledoux J-B (2015) Combining genetic and demographic data for the conservation of a Mediterranean marine habitat-forming species. PloS one 10:e0119585

Austerlitz F, Mariette S, Machon N, Gouyon P-H, Godelle B (2000) Effects of colonization processes on genetic diversity: differences between annual plants and tree species. Genetics 154:1309-1321

Belkhir K, Borsa P, Goudet J, Chikhi L, Bonhomme F (1999) Genetix.

Bell G, Collins S (2008) Adaptation, extinction and global change. Evol Appl 1:3-16

Benestan L, Gosselin T, Perrier C, Sainte-Marie B, Rochette R, Bernatchez L (2015) RAD genotyping reveals fine-scale genetic structuring and provides powerful population assignment in a widely distributed marine species, the American lobster (Homarus americanus). Mol Ecol 24:3299-3315

Boudouresque C-F, Blanfuné A, Fernandez C, Lejeusne C, Pérez T, Ruitton S, Thibault D, Thibaut T, Verlaque M (2017) Marine Biodiversity-Warming vs. Biological Invasions and overfishing in the Mediterranean Sea: Take care, 'One Train can hide another.' MOJ Ecology \& Environmental Science 2:1-13

Cánovas-Molina A, Montefalcone M, Bavestrello G, Masmoudi MB, Haguenauer A, Hammami P, Chaoui L, Kara MH, Aurelle D (2018) From depth to regional spatial genetic differentiation of Eunicella cavolini in the NW Mediterranean. C R Biol 341:421-432

Chapuis M-P, Estoup A (2007) Microsatellite null alleles and estimation of population differentiation. Mol Biol Evol 24:621-631

Cigliano M, Gambi MC (2007) The long hot summer: a further mortality event of Gorgonians along the Phlaegrean islands (Tyrrhenian Sea). Biol Mar Med 14:292-293

Coll M, Piroddi C, Albouy C, Ben Rais Lasram F, Cheung WW, Christensen V, Karpouzi VS, Guilhaumon F, Mouillot D, Paleczny M (2012) The Mediterranean Sea under siege: spatial overlap between marine biodiversity, cumulative threats and marine reserves. Glob Ecol Biogeogr 21:465-480

Coll M, Piroddi C, Steenbeek J, Kaschner K, Lasram FBR, Aguzzi J, Ballesteros E, Bianchi CN, Corbera J, Dailianis T (2010) The biodiversity of the Mediterranean Sea: estimates, patterns, and threats. PloS one 5:e11842

Colson I, Hughes RN (2004) Rapid recovery of genetic diversity of dogwhelk (Nucella lapillus L.) populations after local extinction and recolonization contradicts predictions from life history characteristics. Mol Ecol 13:2223-2233 
Coma R, Ribesl RM, Zabala M, Gilil J-M (1995) Reproduction and cycle of gonadal development in the Mediterranean gorgonian Paramuricea clavata. Mar Ecol Prog Ser 117:173-183

Costantini F, Fauvelot C, Abbiati M (2007) Fine-scale genetic structuring in Corallium rubrum: evidence of inbreeding and limited effective larval dispersal. Mar Ecol Prog Ser 340:109_ 119

Cramer W, Guiot J, Fader M, Garrabou J, Gattuso J-P, Iglesias A, Lange MA, Lionello P, Llasat MC, Paz S (2018) Climate change and interconnected risks to sustainable development in the Mediterranean. Nat Clim Chang 8(11):972-980.

Cupido R, Cocito S, Manno V, Ferrando S, Peirano A, Iannelli M, Bramanti L, Santangelo G (2012) Sexual structure of a highly reproductive, recovering gorgonian population: quantifying reproductive output. Mar Ecol Prog Ser 469:25-36

Dafforn KA, Glasby TM, Airoldi L, Rivero NK, Mayer-Pinto M, Johnston EL (2015) Marine urbanization: an ecological framework for designing multifunctional artificial structures. Front Ecol Environ 13:82-90

D’Aloia CC, Bogdanowicz SM, Francis RK, Majoris JE, Harrison RG, Buston PM (2015) Patterns, causes, and consequences of marine larval dispersal. Proc Natl Acad Sci U S A 112:1394013945

Fauvelot C, Bertozzi F, Costantini F, Airoldi L, Abbiati M (2009) Lower genetic diversity in the limpet Patella caerulea on urban coastal structures compared to natural rocky habitats. Mar Biol 156:2313-2323

Foll M, Gaggiotti O (2006) Identifying the environmental factors that determine the genetic structure of populations. Genetics 174:875-891

Francis RM (2017) pophelper: an R package and web app to analyse and visualize population structure. Mol Ecol Res 17:27-32

Gaggiotti OE, Foll M (2010) Quantifying population structure using the F model. Mol Ecol Res 10:821-830

Gambi M (2014) L'isola d’Ischia: un osservatorio speciale per lo studio del cambiamento climatico globale a mare. In: Greco P Ed.: Ischia Patrimonio dell’Umanità Natura e cultura Doppiavoce Ed, Napoli 71-97

Gambi M, Barbieri F (2012) Population structure of the gorgonian Eunicella cavolinii in the "Grotta Azzurra” cave off Palinuro, after the mass mortality event in 2008. Biol Mar Mediter 19:174

Gambi M, Barbieri F, Signorelli S, Saggiomo V (2010) Mortality events along the Campania coast (Tyrrhenian Sea) in summers 2008 and 2009 and relation to thermal conditions. Biol Mar Mediter 17:126

Gambi M, Cigliano M, Iacono B (2006) Segnalazione di un evento di mortalità di gorgonacei lungo le coste delle isole di Ischia e Procida (Golfo di Napoli, Mar Tirreno). Biol Mar Mediter 13:583-587

Garrabou J, Coma R, Bensoussan N, Bally M, Chevaldonné P, Cigliano M, Diaz D, Harmelin JG, Gambi MC, Kersting DK, Ledoux J-B, Lejeusne C, Linares C, Marschal C, Pérez T, Ribes M, Romano JC, Serrano E, Teixido N, Torrents O, Zabala M, Zuberer F, Cerrano C (2009) 
Mass mortality in Northwestern Mediterranean rocky benthic communities: effects of the 2003 heat wave. Glob Chang Biol 15:1090-1103

Gattuso J-P, Magnan AK, Bopp L, Cheung WW, Duarte CM, Hinkel J, Mcleod E, Micheli F, Oschlies A, Williamson P (2018) Ocean solutions to address climate change and its effects on marine ecosystems. Front Mar Sci 5:337

Glover KA, Hansen MM, Lien S, Als TD, Høyheim B, Skaala Ø (2010) A comparison of SNP and STR loci for delineating population structure and performing individual genetic assignment. BMC Genetics 11:2

Haguenauer A, Zuberer F, Ledoux J-B, Aurelle D (2013) Adaptive abilities of the Mediterranean red coral Corallium rubrum in a heterogeneous and changing environment: from population to functional genetics. J Exp Mar Bio Ecol 449:349-357

Hughes TP, Kerry JT, Baird AH, Connolly SR, Chase TJ, Dietzel A, Hill T, Hoey AS, Hoogenboom MO, Jacobson M (2019) Global warming impairs stock-recruitment dynamics of corals. Nature 568:387

Jombart T (2008) adegenet: a R package for the multivariate analysis of genetic markers. Bioinformatics 24:1403-1405

Kamvar ZN, Brooks JC, Grünwald NJ (2015) Novel R tools for analysis of genome-wide population genetic data with emphasis on clonality. Front Gen 6:208

Kamvar ZN, Tabima JF, Grünwald NJ (2014) Poppr: an R package for genetic analysis of populations with clonal, partially clonal, and/or sexual reproduction. PeerJ 2:e281

Ledoux J, Frleta Valić M, Kipson S, Antunes A, Cebrian E, Linares C, Sánchez P, Leblois R, Garrabou J (2018) Postglacial range expansion shaped the spatial genetic structure in a marine habitat forming species: Implications for conservation plans in the Eastern Adriatic Sea. J Biogeogr 45:2645-2657

Ledoux J, Garrabou J, Bianchimani O, Drap P, Féral J-P, Aurelle D (2010a) Fine-scale genetic structure and inferences on population biology in the threatened Mediterranean red coral, Corallium rubrum. Mol Ecol 19:4204-4216

Ledoux J-B, Mokhtar-Jamaï K, Roby C, Féral J-P, Garrabou J, Aurelle D (2010b) Genetic survey of shallow populations of the Mediterranean red coral [Corallium rubrum (Linnaeus, 1758)]: new insights into evolutionary processes shaping nuclear diversity and implications for conservation. Mol Ecol 19:675-690

Ledoux J-B, Aurelle D, Bensoussan N, Marschal C, Féral J-P, Garrabou J (2015) Potential for adaptive evolution at species range margins: contrasting interactions between red coral populations and their environment in a changing ocean. Ecol Evol 5:1178-1192

Linares C, Coma R, Mariani S, Díaz D, Hereu B, Zabala M (2008) Early life history of the Mediterranean gorgonian Paramuricea clavata: implications for population dynamics. Invertebr Biol 127:1-11

Linares C, Doak DF, Coma R, Diaz D, Zabala M (2007) Life history and viability of a long-lived marine invertebrate: the octocoral Paramuricea clavata. Ecology 88:918-928 
endangered copper redhorse, Moxostoma hubbsi (Catostomidae, Pisces): the positive sides of a long generation time. Mol Ecol 15:1769-1780

Manel S, Perrier C, Pratlong M, Abi-Rached L, Paganini J, Pontarotti P, Aurelle D (2016) Genomic resources and their influence on the detection of the signal of positive selection in genome scans. Mol Ecol 25:170-184

Martínez-Quintana A, Bramanti L, Viladrich N, Rossi S, Guizien K (2015) Quantification of larval traits driving connectivity: the case of Corallium rubrum (L. 1758). Mar Biol 162:309-318

Masmoudi MB, Chaoui L, Topçu NE, Hammami P, Kara MH, Aurelle D (2016) Contrasted levels of genetic diversity in a benthic Mediterranean octocoral: Consequences of different demographic histories? Ecol Evol 6:8665-8678

Mokhtar-Jamai K, Pascual M, Ledoux J-B, Coma R, Féral J-P, Garrabou J, Aurelle D (2011) From global to local genetic structuring in the red gorgonian Paramuricea clavata: the interplay between oceanographic conditions and limited larval dispersal. Mol Ecol 20:3291-3305

Molecular Ecology Resources Primer Development Consortium, Aurelle D, Baker AJ, Bottin L, Brouat C, Caccone A, Chaix A, Dhakal P, Ding Y, Duplantier JM, Fiedler W, Fietz J, Fong Y, Forcioli D, Freitas TRO, Gunnarson GH, Haddrath O, Hadziabdic D, Hauksdottir S, Havill NP, Heinrich M, Heinz T, Hjorleifsdottir S, Hong Y, Hreggvidsson GO, Huchette S, Hurst J, Kane M, Kane NC, Kawakamit T,Ke W, Keith RA, Klauke N, Klein JL, Kun JFJ, Li C, Li G-Q, Li J-J, Loiseau A, Lu L-Z, Lucas M, Martins-Ferreira C, Mokhtar-Jamaï K, Olafsson K, Pampoulie C, Pan L, Pooler MR, Ren J-D, Rinehart TA, Roussel V, Santos MO, Schaefer HM, Scheffler BE, Schmidt A, Segelbacher G, Shen J-D, Skirnisdottir S, Sommer S, Tao Z-R, Taubert R, Tian Y, Tomiuk J, Trigiano RN, Ungerer MC, Van Wormhoudt A, Wadl PA, Wang D-Q, Weis-Dootz T, Xia Q, Yuan Q-Y (2010) Permanent Genetic Resources added to the Molecular Ecology Resources Database 1 February 2010 31 March 2010. Mol Ecol Res 10:751-754

Ordóñez V, Pascual M, Rius M, Turon X (2013) Mixed but not admixed: a spatial analysis of genetic variation of an invasive ascidian on natural and artificial substrates. Mar Biol 160:1645-1660

Orsini L, Vanoverbeke J, Swillen I, Mergeay J, Meester L (2013) Drivers of population genetic differentiation in the wild: isolation by dispersal limitation, isolation by adaptation and isolation by colonization. Mol Ecol 22:5983-5999

Otto SP (2018) Adaptation, speciation and extinction in the Anthropocene. Proc R Soc Lond B Biol Sci 285:20182047

Padrón M, Costantini F, Bramanti L, Guizien K, Abbiati M (2018) Genetic connectivity supports recovery of gorgonian populations affected by climate change. Aquat Conserv 28:776-787

Paetkau D, Slade R, Burden M, Estoup A (2004) Genetic assignment methods for the direct, realtime estimation of migration rate: a simulation-based exploration of accuracy and power. Mol Ecol 13:55-65

Pérez-Portela R, Cerro-Gálvez E, Taboada S, Tidu C, Campillo-Campbell C, Mora J, Riesgo A (2016) Lonely populations in the deep: genetic structure of red gorgonians at the heads of submarine canyons in the north-western Mediterranean Sea. Coral Reefs 35:1013-1026 
connectivity in the Mediterranean red gorgonian coral after mass mortality events. PloS one 11:e0150590

Pilczynska J, Cocito S, Boavida J, Serrão EA, Assis J, Fragkopoulou E, Queiroga H (2019) Genetic diversity increases with depth in red gorgonian populations of the Mediterranean Sea and the Atlantic Ocean. PeerJ 7:e6794

Piry S, Alapetite A, Cornuet J-M, Paetkau D, Baudouin L, Estoup A (2004) GENECLASS2: A Software for Genetic Assignment and First-Generation Migrant Detection. J Hered 95:536539

Pivotto I, Nerini D, Masmoudi M, Kara H, Chaoui L, Aurelle D (2015) Highly contrasted responses of Mediterranean octocorals to climate change along a depth gradient. R Soc Open Sci 2:140493

Pratlong M, Haguenauer A, Brener K, Mitta G, Toulza E, Garrabou J, Bensoussan N, Pontarotti P, Aurelle D (2018) Separate the wheat from the chaff: genomic analysis of local adaptation in the red coral Corallium rubrum. bioRxiv, 306456, ver. 3 peer-reviewed and recommended by PCI Evol Biol

Pritchard JK, Stephens M, Donnelly P (2000) Inference of Population Structure Using Multilocus Genotype Data. Genetics 155:945-959

Rannala B, Mountain JL (1997) Detecting immigration by using multilocus genotypes. Proc Natl Acad Sci U S A 64:9197-9201

Ribout C, Carpentieri C (2013) Automated genomic DNA purification of marine organisms on the epMotion ${ }^{\circledR} 5075$ VAC from Eppendorf. Eppendorf Application Note 281:1-6

Ronce O (2007) How does it feel to be like a rolling stone? Ten questions about dispersal evolution. Annu Rev Ecol Evol Syst 38:231-253

Rousset F (2008) genepop’007: a complete re-implementation of the genepop software for Windows and Linux. Mol Ecol Res 8:103-106

Starger C, Barber P, Baker A (2010) The recovery of coral genetic diversity in the Sunda Strait following the 1883 eruption of Krakatau. Coral Reefs 29:547-565

Szpiech ZA, Jakobsson M, Rosenberg NA (2008) ADZE: a rarefaction approach for counting alleles private to combinations of populations. Bioinformatics 24:2498-2504

Underwood JN, Smith LD, Van Oppen MJH, Gilmour JP (2007) Multiple scales of genetic connectivity in a brooding coral on isolated reefs following catastrophic bleaching. Mol Ecol 16:771-784

Verdura J, Linares C, Ballesteros E, Coma R, Uriz MJ, Bensoussan N, Cebrian E (2019) Biodiversity loss in a Mediterranean ecosystem due to an extreme warming event unveils the role of an engineering gorgonian species. Sci Rep 9:5911

Wang J (2002) An estimator for pairwise relatedness using molecular markers. Genetics 160:12031215

Wang J (2011) COANCESTRY: a program for simulating, estimating and analysing relatedness and inbreeding coefficients. Mol Ecol Res 11:141-145 
655 Weinberg S (1979) The light-dependent behaviour of planula larvae of Eunicella singularis and $656 \quad$ Corallium rubrum and its implication for octocorallian ecology. Bijdragen tot de Dierkunde $657 \quad 49: 16-30$

658 Weir BS, Cockerham CC (1984) Estimating F-statistics for the analysis of population structure. $659 \quad$ Evolution 38:1358-1370

660 


\section{Figure legends:}

662 Figure 1: sampling locations for Paramuricea clavata and Eunicella cavolini. Asterisks indicate 663 populations issued from colonization (wrecks for $P$. clavata) or recolonization after mortality event 664 (E. cavolini). Maps were produced with SimpleMappr (Shorthouse, 2010).

666 Figure 2 : plots of PCA results. A) Paramuricea clavata with axis 1 (2.7 \% of variance) horizontal 667 and axis 2 (2.4\% of variance) vertical; B) P. clavata with axis 1 horizontal and axis 3 (2.2\% of 668 variance) vertical. C) Eunicella cavolini with axis 1 (4.7\% of variance) horizontal and axis 2 (4.4\% 669 of variance) vertical; D) E. cavolini with axis 1 horizontal and axis 3 (3.9 \% of variance) vertical. 670

671 Figure 3: results for the individual clustering analysis with STRUCTURE for A) Paramuricea 672 clavata and B) Eunicella cavolini. 
1 Table 1, samples description: codes of sampling sites, GPS coordinates, depth, sample size

2 without repeated MLGs (N), mean number of alleles per locus rarefied for g individuals ( $\operatorname{Ar}(\mathrm{g})$; $\mathrm{g}=$

329 for Paramuricea clavata, except for PQL with g = 12; and 14 for Eunicella cavolini, except UST

4 with $g=10)$, observed heterozygosity $\left(\mathrm{H}_{\mathrm{O}}\right)$ and expected heterozygosity $\left(\mathrm{H}_{\mathrm{E}}\right)$, multilocus $\mathrm{F}_{\mathrm{IS}}$ (values

5 in bold correspond to significant test of panmixia after FDR correction at a 0.05 level).

6

\begin{tabular}{llllllllll}
\hline site & code & GPS & $\begin{array}{l}\text { depth } \\
(\mathrm{m})\end{array}$ & year & $\mathrm{N}$ & $\operatorname{Ar}(\mathrm{g})$ & $\mathrm{H}_{\mathrm{O}}$ & $\mathrm{H}_{\mathrm{E}}$ & $\mathrm{F}_{\mathrm{IS}}$ \\
\hline
\end{tabular}

\begin{tabular}{|c|c|c|c|c|c|c|c|c|c|}
\hline \multicolumn{10}{|c|}{ Paramuricea clavata } \\
\hline $\begin{array}{l}\text { Pointe du } \\
\text { Vaisseau }\end{array}$ & PTV & $\begin{array}{l}42^{\circ} 59^{\prime} 42.9^{\prime \prime} \mathrm{N} \\
6^{\circ} 24^{\prime} 24.2^{\prime \prime} \mathrm{E}\end{array}$ & $20-25$ & 2008 & 29 & 7.2 & 0.59 & 0.63 & 0.06 \\
\hline Donator wreck & DON & $\begin{array}{l}42^{\circ} 59 ' 35.9 " \mathrm{~N} \\
6^{\circ} 16^{\prime} 26.1^{\prime \prime} \mathrm{E}\end{array}$ & 34 & 2011 & 33 & 7.6 & 0.58 & 0.62 & 0.08 \\
\hline Le Grec wreck & GRE & $\begin{array}{l}42^{\circ} 59 ' 37.0 " \mathrm{~N} \\
6^{\circ} 16^{\prime} 42.0^{\prime \prime} \mathrm{E}\end{array}$ & 34 & 2011 & 33 & 7.7 & 0.61 & 0.65 & 0.06 \\
\hline $\begin{array}{l}\text { Sec de } \\
\text { Sarraniers }\end{array}$ & SAR & $\begin{array}{l}42^{\circ} 59 ' 16.3^{\prime \prime N} \\
6^{\circ} 17^{\prime} 30.2^{\prime \prime E}\end{array}$ & 40 & 2011 & 35 & 7.5 & 0.57 & 0.61 & 0.08 \\
\hline Gabinière & GAB & $\begin{array}{l}42^{\circ} 59 ' 21.5^{\prime \prime N} \\
6^{\circ} 23^{\prime} 49.2^{\prime \prime} \mathrm{E}\end{array}$ & $22-25$ & 2008 & 32 & 7.8 & 0.63 & 0.69 & 0.09 \\
\hline Les Mèdes & PQL & $\begin{array}{l}43^{\circ} 01^{\prime} 43.0 " \mathrm{~N} \\
6^{\circ} 14^{\prime} 28.0^{\prime \prime} \mathrm{E}\end{array}$ & 31 & 2009 & 29 & 4.6 & 0.61 & 0.73 & 0.16 \\
\hline Montrémian & MTM & $\begin{array}{l}43^{\circ} 01^{\prime} 07.2^{\prime \prime} \mathrm{N} \\
6^{\circ} 21^{\prime} 46.0^{\prime \prime} \mathrm{E}\end{array}$ & $20-25$ & 2008 & 29 & 6.1 & 0.57 & 0.64 & 0.12 \\
\hline Riou Marseille & RIO & $\begin{array}{l}43^{\circ} 10^{\prime} 21.66^{\prime \prime} \mathrm{N} \\
5^{\circ} 23^{\prime} 25.16 " \mathrm{E}\end{array}$ & $20-25$ & 2008 & 35 & 8.5 & 0.60 & 0.71 & 0.15 \\
\hline Riou Marseille & RIS & $\begin{array}{l}43^{\circ} 10^{\prime} 21.66 " \mathrm{~N} \\
5^{\circ} 23^{\prime} 25.16^{\prime \prime} \mathrm{C}\end{array}$ & 40 & 2008 & 30 & 8.0 & 0.66 & 0.73 & 0.10 \\
\hline $\begin{array}{l}\text { Impériales } \\
\text { Marseille }\end{array}$ & IMP & $\begin{array}{l}43^{\circ} 10^{\prime} 22.79 " \mathrm{~N} \\
5^{\circ} 23^{\prime} 35.39 " \mathrm{E}\end{array}$ & 41 & 2007 & 39 & 8.3 & 0.63 & 0.72 & 0.12 \\
\hline
\end{tabular}

Marseille

Eunicella cavolini

\begin{tabular}{|c|c|c|c|c|c|c|c|c|c|}
\hline $\begin{array}{l}\text { Nisida Island } \\
\text { (Napoli) }\end{array}$ & NISB & $\begin{array}{l}40^{\circ} 47^{\prime} 22.8^{\prime \prime N} \\
14^{\circ} 09^{\prime} 42.0^{\prime \prime} \mathrm{E}\end{array}$ & 20 & 2013 & 16 & 3.8 & 0.54 & 0.58 & 0.08 \\
\hline $\begin{array}{l}\text { Secca Formiche } \\
\text { di Vivara } \\
\text { (Ischia) }\end{array}$ & SFV & $\begin{array}{l}40^{\circ} 44^{\prime} 20.45^{\prime \prime N} \\
13^{\circ} 58^{\prime} 45.08^{\prime \prime} \mathrm{E}\end{array}$ & 15 & 2013 & 38 & 4.5 & 0.64 & 0.65 & 0.01 \\
\hline $\begin{array}{l}\text { Sant'Angelo } \\
\text { (Ischia) }\end{array}$ & SAN & $\begin{array}{l}40^{\circ} 41 ' 30.58^{\prime \prime N} \\
13^{\circ} 53 ' 37.76^{\prime \prime} \mathrm{E}\end{array}$ & $18-20$ & 2013 & 31 & 4.6 & 0.53 & 0.65 & 0.20 \\
\hline $\begin{array}{l}\text { La Nave } \\
\text { (Ischia) }\end{array}$ & LAN & $\begin{array}{l}40^{\circ} 42^{\prime} 25.35 " \mathrm{~N} \\
13^{\circ} 51 ' 12.73^{\prime \prime} \mathrm{E}\end{array}$ & $20-25$ & 2013 & 25 & 5.4 & 0.59 & 0.71 & 0.17 \\
\hline $\begin{array}{l}\text { Grotta Azzura } \\
\text { (Palinuro, } \\
\text { Salerno) }\end{array}$ & GAZ & $\begin{array}{l}40^{\circ} 1 ' 53.01 " \mathrm{~N} \\
15^{\circ} 16^{\prime} 9.01 " \mathrm{E}\end{array}$ & 15 & 2013 & 32 & 4.9 & 0.66 & 0.70 & 0.06 \\
\hline $\begin{array}{l}\text { Ustica Island } \\
\text { Secchitello } \\
\text { (Palermo) }\end{array}$ & UST & $\begin{array}{l}38^{\circ} 41 ' 25.54 " \mathrm{~N} \\
13^{\circ} 10^{\prime} 25.35^{\prime \prime} \mathrm{E}\end{array}$ & $35-38$ & 2013 & 14 & 4.0 & 0.61 & 0.63 & 0.04 \\
\hline
\end{tabular}


10 Table 2, comparisons of relatedness levels: comparison of within-population relatedness levels

11 based on the estimator of Wang (2002), A) for Paramuricea clavata, and B) for Eunicella cavolini.

12 Each comparison corresponds to the observed difference in mean relatedness between population in

13 column and population in row. Blue and red values indicate significantly positive and negative

14 differences respectively. Asterisk indicate extreme values based on 1000 bootstraps, with the

15 corresponding percentiles: * $5 \% * * 2.5 \% * * * 1 \%$.

16

17 A) P. clavata

\begin{tabular}{|c|c|c|c|c|c|c|c|c|c|}
\hline & PTV & DON & GRE & SAR & GAB & PQL & MTM & RIO & RIS \\
\hline \multicolumn{10}{|l|}{ PTV } \\
\hline DON & $0.083^{* * *}$ & & & & & & & & \\
\hline GRE & $0.074^{* * *}$ & -0.0092 & & & & & & & \\
\hline SAR & $0.065^{* * *}$ & -0.018 & -0.0094 & & & & & & \\
\hline GAB & $0.11^{* * *}$ & $0.031^{* * *}$ & $0.032^{* * *}$ & $0.041^{* * *}$ & & & & & \\
\hline PQL & $0.12^{* * *}$ & $0.036^{* * *}$ & $0.045^{* * *}$ & $0.054^{* * *}$ & 0.013 & & & & \\
\hline MTM & -0.019 & $-0.1 * * *$ & $-0.093 * * *$ & $-0.084^{* * *} *$ & $-0.13^{* * *}$ & $-0.14^{* * *} *$ & & & \\
\hline RIO & $0.14^{* * *}$ & $0.053^{* * *}$ & $0.062^{* * *}$ & $0.071^{* * *}$ & $0.03^{* * *}$ & 0.017 & $0.16 * * *$ & & \\
\hline RIS & $0.076^{* * *}$ & -0.0073 & 0.0019 & 0.011 & $-0.03^{* * *}$ & $-0.043^{* * *}$ & $0.095^{* * *}$ & $-0.06^{* * *}$ & \\
\hline IMP & $0.11^{* * *}$ & $0.029 * * *$ & $0.038 * * *$ & $0.047^{* * *}$ & 0.0056 & -0.0073 & $0.13^{* * *}$ & $-0.024 * * *$ & $0.036 * * *$ \\
\hline
\end{tabular}

18

19 B) E. cavolini

\begin{tabular}{|c|c|c|c|c|c|c|}
\hline & NISB & SFV & SAN & LAN & GAZ & UST \\
\hline \multicolumn{7}{|l|}{ NISB } \\
\hline SFV & $0.14 * * *$ & & & & & \\
\hline SAN & $0.21 * * *$ & $0.071 * * *$ & & & & \\
\hline LAN & $0.3^{* * *}$ & $0.15^{* * *}$ & $0.081 * * *$ & & & \\
\hline GAZ & $0.21 * * *$ & $0.073 * * *$ & 0.0026 & $-0.079 * * *$ & & \\
\hline UST & $0.2 * * *$ & $0.2 * * *$ & -0.0061 & $-0.087^{* *}$ & -0.0086 & \\
\hline
\end{tabular}


23 Table 3: pairwise $\mathrm{F}_{\mathrm{ST}}$ values for A) Paramuricea clavata, and B) Eunicella cavolini. Below

24 diagonal: standard $\mathrm{F}_{\mathrm{ST}}$ estimates (Weir and Cockerham 1984); above diagonal: $\mathrm{F}_{\mathrm{ST}}$ estimates from

25 FreeNA. Values in bold correspond to significant genic differentiation after FDR correction at a

260.05 level.

27

28

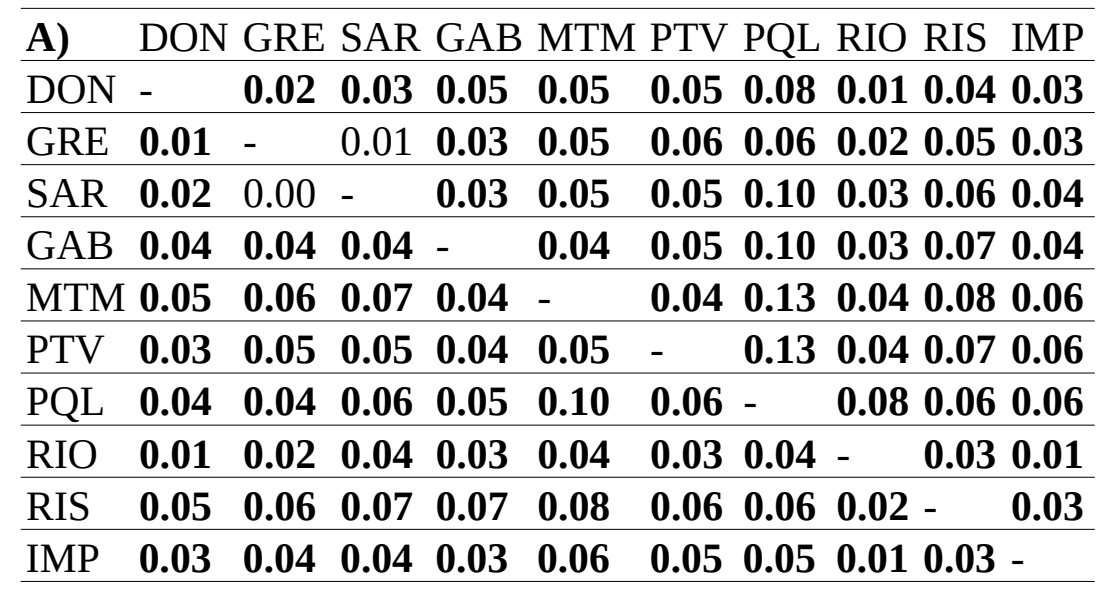

B) GAZ LAN NISB SAN SFV UST

\begin{tabular}{lllllll}
\hline GAZ & - & 0.08 & 0.08 & 0.07 & 0.06 & 0.05 \\
\hline LAN & $\mathbf{0 . 0 8}$ & - & 0.12 & 0.07 & 0.07 & 0.11 \\
\hline NISB & $\mathbf{0 . 1 1}$ & $\mathbf{0 . 0 5}$ & - & 0.03 & 0.05 & 0.07 \\
\hline SAN & $\mathbf{0 . 1 0}$ & $\mathbf{0 . 0 4}$ & $\mathbf{0 . 0 4}$ & - & $\mathbf{0 . 0 2}$ & $\mathbf{0 . 0 7}$ \\
\hline SFV & $\mathbf{0 . 0 9}$ & $\mathbf{0 . 0 4}$ & $\mathbf{0 . 0 6}$ & $\mathbf{0 . 0 4}$ & - & $\mathbf{0 . 0 7}$ \\
\hline UST & $\mathbf{0 . 1 0}$ & $\mathbf{0 . 1 3}$ & $\mathbf{0 . 1 2}$ & $\mathbf{0 . 1 1}$ & $\mathbf{0 . 1 2}$ & - \\
\hline
\end{tabular}


32 Table 4: estimates of local $F_{\text {ST }}$ with 95\% highest probability density interval (HPDI).

33

\begin{tabular}{lll}
\hline Population & mean & $95 \%$ HPDI \\
\hline P. clavata & & \\
\hline DON & 0.08 & $0.0556 ; 0.109$ \\
\hline GRE & 0.08 & $0.0545 ; 0.107$ \\
\hline SAR & 0.07 & $0.0471 ; 0.0950$ \\
\hline GAB & 0.05 & $0.0327 ; 0.0768$ \\
\hline MTM & 0.12 & $0.0779 ; 0.162$ \\
\hline PTV & 0.08 & $0.0514 ; 0.109$ \\
\hline PQL & 0.23 & $0.165 ; 0.295$ \\
\hline RIO & 0.03 & $0.0205 ; 0.0498$ \\
\hline RIS & 0.07 & $0.0489 ; 0.0960$ \\
\hline IMP & 0.05 & $0.0327 ; 0.0671$
\end{tabular}

E. cavolini

\begin{tabular}{lll}
\hline GAZ & 0.15 & $0.0940 ; 0.208$ \\
\hline LAN & 0.18 & $0.117 ; 0.238$ \\
\hline NISB & 0.30 & $0.188 ; 0.427$ \\
\hline SAN & 0.17 & $0.107 ; 0.235$ \\
\hline SFV & 0.22 & $0.142 ; 0.302$ \\
\hline UST & 0.24 & $0.144 ; 0.332$
\end{tabular}




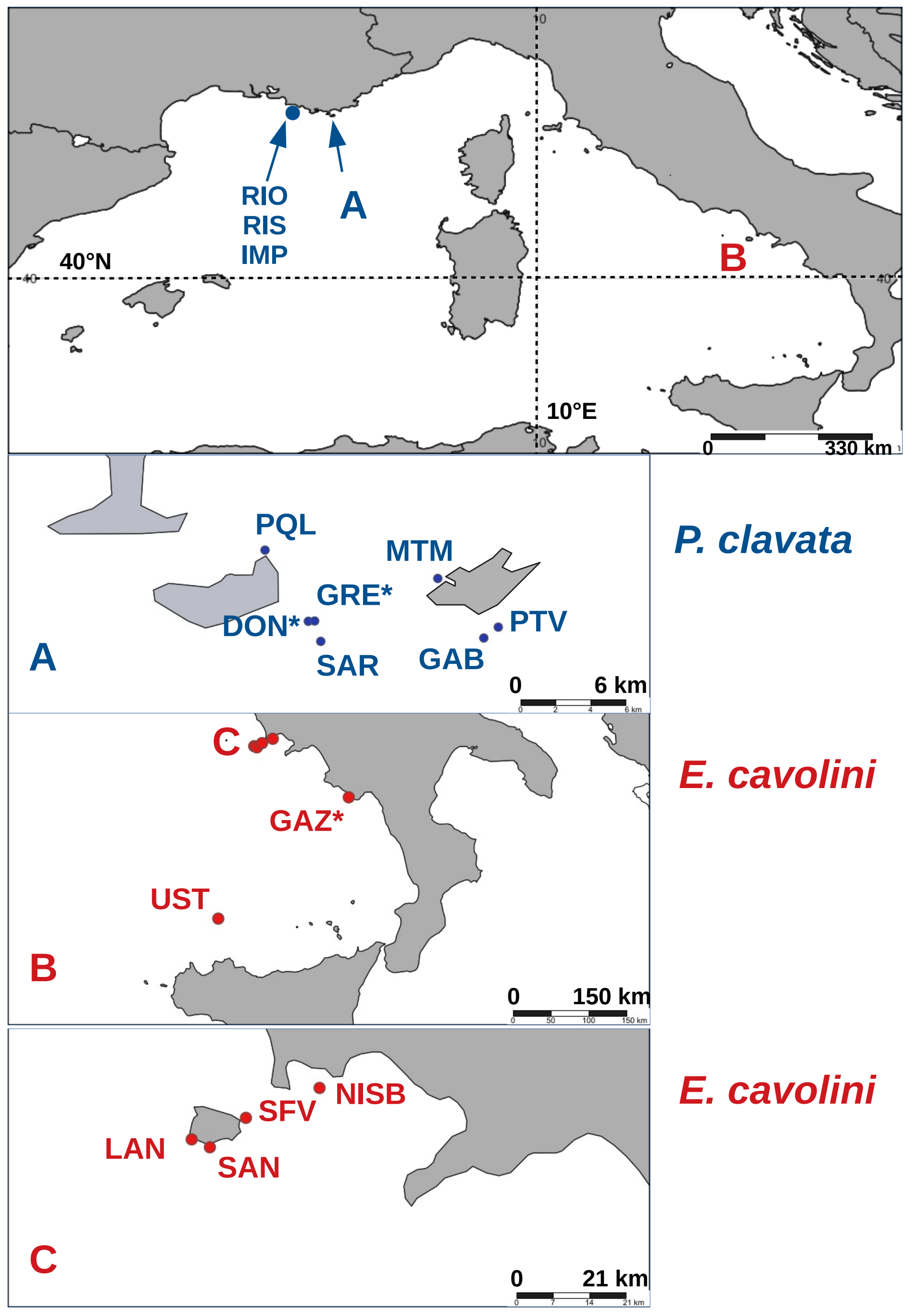




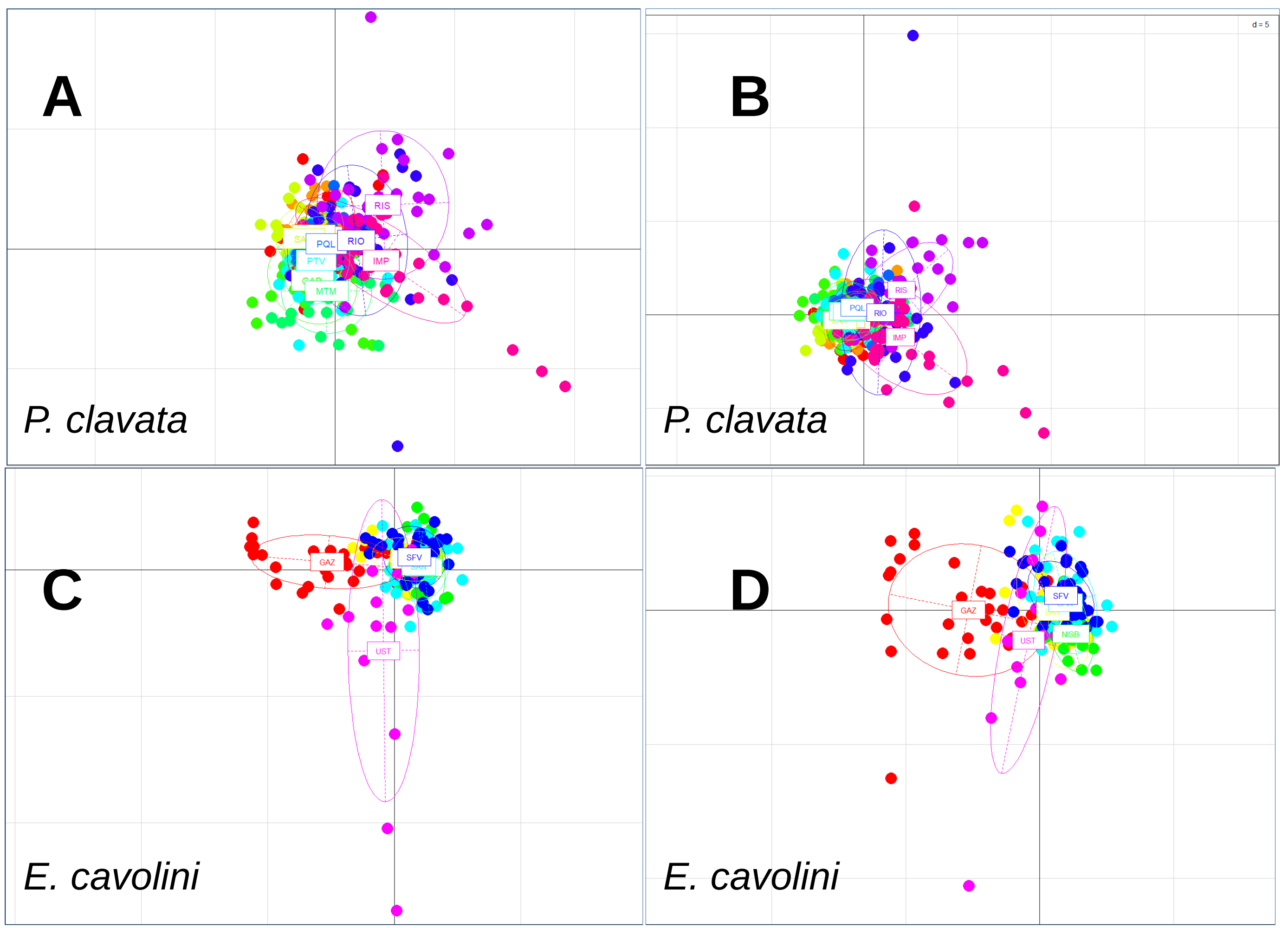




\section{A) P. clavata}

$K=2$

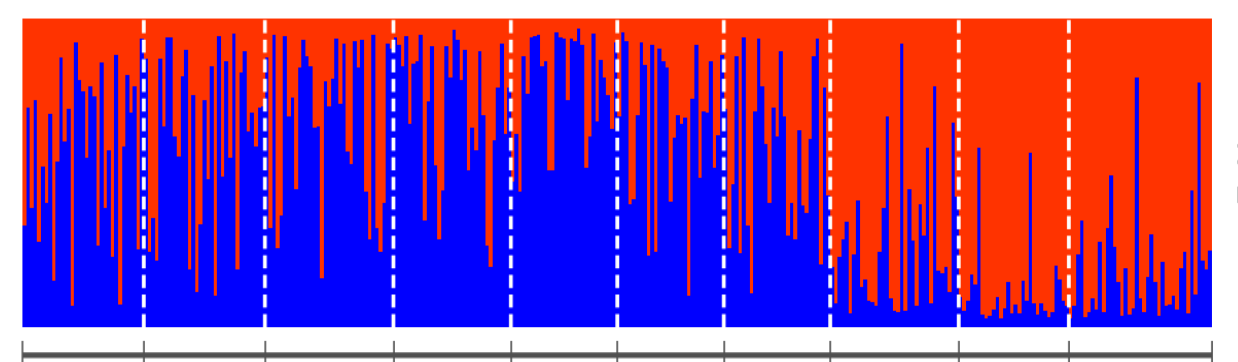

$K=3$

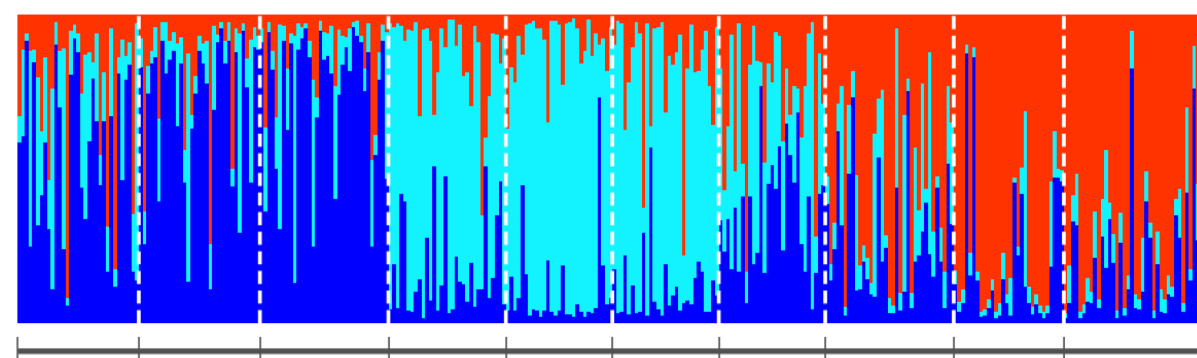

$K=4$

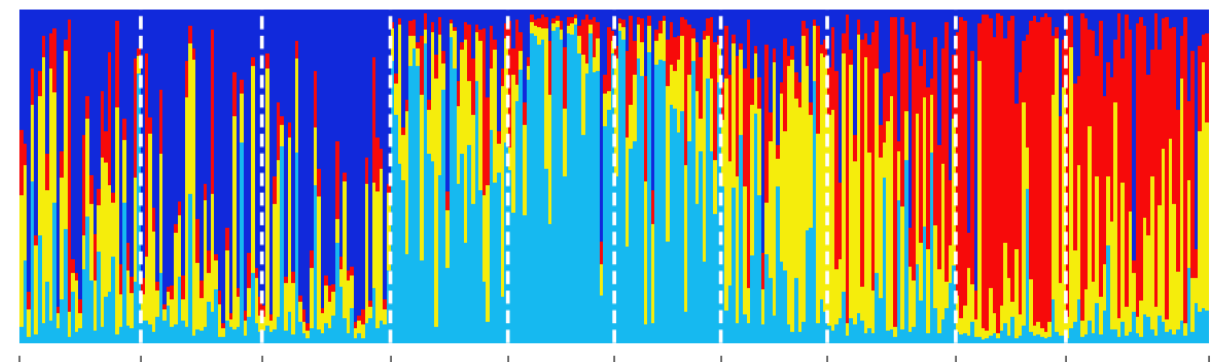

$K=5$

\section{B) E. cavolini}
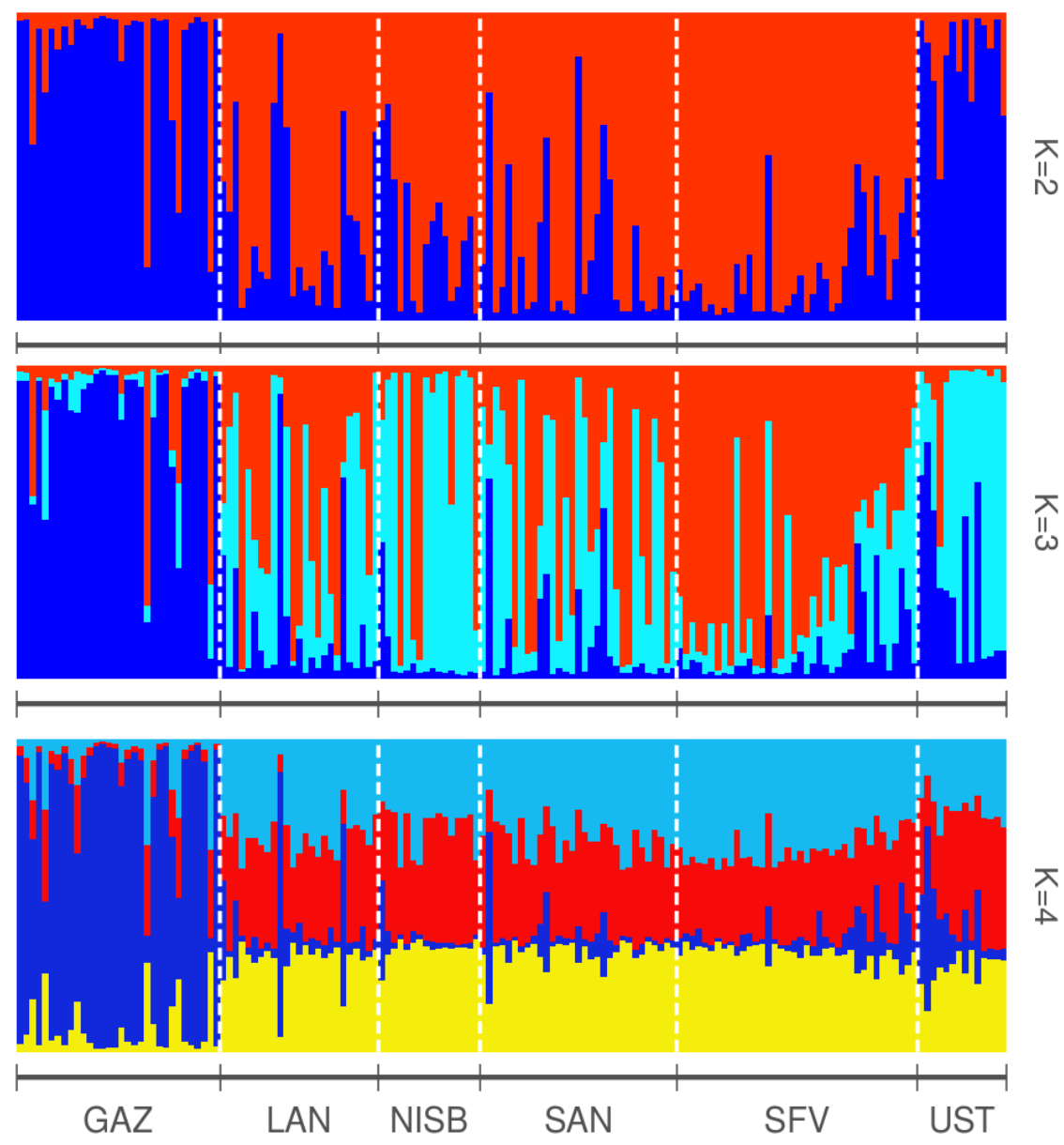

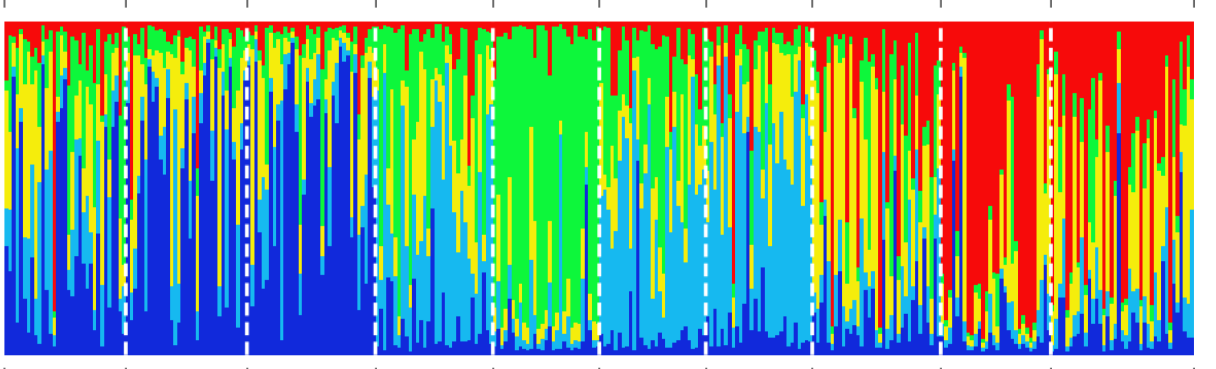




\title{
Genetic insights into recolonization processes of Mediterranean octocorals
}

\author{
Authors : D. Aurelle, J. Tariel, F. Zuberer, A. Haguenauer, C. Ribout, M. Masmoudi, H. Kara,
}

\section{Chaoui, J. Garrabou, J.-B. Ledoux, M. C. Gambi}

Supplementary Table 1: results of the assignment of individuals to other populations. For the three focal populations DON, GRE and GAZ, we indicate the probability of each individual to belong to each of the other analyzed population. Bold values correspond to probabilities superior or equal to 0.95. The mean of individual probabilities is given for each potential source population.

a) Paramuricea clavata

\begin{tabular}{|c|c|c|c|c|c|c|c|c|}
\hline & SAR & GAB & MTM & PTV & PQL & RIO & RIS & IMP \\
\hline DON1 & 0.097 & 0.009 & 0.000 & 0.011 & 0.421 & 0.014 & 0.255 & 0.106 \\
\hline DON2 & 0.498 & 0.620 & 0.206 & 0.116 & 0.175 & 0.742 & 0.086 & 0.067 \\
\hline DON3 & 0.455 & 0.022 & 0.002 & 0.000 & 0.123 & 0.396 & 0.285 & 0.083 \\
\hline DON4 & 0.323 & 0.686 & 0.068 & 0.160 & 0.707 & 0.457 & 0.303 & 0.108 \\
\hline DON5 & 0.365 & 0.083 & 0.000 & 0.004 & 0.008 & 0.042 & 0.425 & 0.078 \\
\hline DON6 & 0.123 & 0.320 & 0.002 & 0.061 & 0.081 & 0.163 & 0.309 & 0.376 \\
\hline DON7 & 0.012 & 0.002 & 0.000 & 0.006 & 0.664 & 0.014 & 0.016 & 0.058 \\
\hline DON8 & 0.375 & 0.221 & 0.059 & 0.155 & 0.124 & 0.226 & 0.695 & 0.108 \\
\hline DON9 & 0.008 & 0.010 & 0.000 & 0.007 & 0.577 & 0.039 & 0.057 & 0.051 \\
\hline DON10 & 0.176 & 0.498 & 0.061 & 0.060 & 0.681 & 0.614 & 0.325 & 0.222 \\
\hline DON11 & 0.973 & 0.335 & 0.050 & 0.166 & 0.161 & 0.462 & 0.639 & 0.227 \\
\hline DON12 & 0.552 & 0.072 & 0.014 & 0.097 & 0.993 & 0.906 & 0.301 & 0.676 \\
\hline DON13 & 0.056 & 0.049 & 0.002 & 0.022 & 0.364 & 0.005 & 0.000 & 0.012 \\
\hline DON14 & 0.078 & 0.003 & 0.008 & 0.058 & 0.828 & 0.227 & 0.913 & 0.764 \\
\hline DON15 & 0.433 & 0.022 & 0.055 & 0.033 & 0.537 & 0.019 & 0.334 & 0.057 \\
\hline DON16 & 0.313 & 0.003 & 0.000 & 0.001 & 0.767 & 0.012 & 0.055 & 0.006 \\
\hline DON17 & 0.922 & 0.658 & 0.045 & 0.005 & 0.944 & 0.827 & 0.641 & 0.515 \\
\hline DON18 & 0.818 & 0.269 & 0.487 & 0.819 & 0.988 & 0.999 & 0.752 & 0.928 \\
\hline DON19 & 0.377 & 0.006 & 0.061 & 0.027 & 0.902 & 0.272 & 0.063 & 0.137 \\
\hline DON20 & 0.475 & 0.116 & 0.069 & 0.364 & 1.000 & 0.909 & 0.131 & 0.510 \\
\hline DON21 & 0.534 & 0.346 & 0.010 & 0.049 & 0.647 & 0.399 & 0.446 & 0.298 \\
\hline DON22 & 0.932 & 0.425 & 0.272 & 0.066 & 0.690 & 0.983 & 0.265 & 0.598 \\
\hline DON23 & 0.552 & 0.107 & 0.014 & 0.073 & 1.000 & 0.323 & 0.506 & 0.604 \\
\hline DON24 & 0.077 & 0.010 & 0.001 & 0.007 & 0.040 & 0.034 & 0.032 & 0.178 \\
\hline DON25 & 0.420 & 0.290 & 0.086 & 0.183 & 0.893 & 0.990 & 0.440 & 0.974 \\
\hline DON26 & 0.466 & 0.050 & 0.105 & 0.333 & 0.649 & 0.560 & 0.051 & 0.168 \\
\hline DON27 & 0.006 & 0.002 & 0.000 & 0.020 & 0.907 & 0.031 & 0.561 & 0.096 \\
\hline DON28 & 0.954 & 0.260 & 0.059 & 0.002 & 0.594 & 0.770 & 0.462 & 0.785 \\
\hline DON29 & 0.723 & 0.117 & 0.221 & 0.403 & 0.600 & 0.827 & 0.405 & 0.665 \\
\hline DON30 & 0.328 & 0.009 & 0.000 & 0.005 & 0.672 & 0.027 & 0.069 & 0.049 \\
\hline
\end{tabular}




\begin{tabular}{|c|c|c|c|c|c|c|c|c|}
\hline DON31 & 0.836 & 0.178 & 0.001 & 0.043 & 1.000 & 0.605 & 0.464 & 0.836 \\
\hline DON32 & 0.049 & 0.056 & 0.021 & 0.021 & 0.092 & 0.313 & 0.239 & 0.343 \\
\hline DON33 & 0.962 & 0.899 & 0.876 & 0.536 & 0.970 & 0.918 & 0.655 & 0.714 \\
\hline mean & 0.432 & 0.205 & 0.087 & 0.119 & 0.600 & 0.428 & 0.339 & 0.345 \\
\hline GRE1 & 0.707 & 0.208 & 0.000 & 0.011 & 0.761 & 0.165 & 0.302 & 0.167 \\
\hline GRE2 & 0.491 & 0.144 & 0.005 & 0.091 & 0.965 & 0.136 & 0.610 & 0.667 \\
\hline GRE3 & 0.138 & 0.146 & 0.011 & 0.002 & 0.660 & 0.218 & 0.102 & 0.007 \\
\hline GRE4 & 0.091 & 0.004 & 0.000 & 0.000 & 0.002 & 0.014 & 0.079 & 0.001 \\
\hline GRE5 & 0.781 & 0.157 & 0.116 & 0.001 & 0.426 & 0.821 & 0.025 & 0.181 \\
\hline GRE6 & 0.663 & 0.287 & 0.023 & 0.048 & 0.999 & 0.262 & 0.491 & 0.924 \\
\hline GRE7 & 0.619 & 0.005 & 0.002 & 0.001 & 0.862 & 0.027 & 0.051 & 0.103 \\
\hline GRE8 & 0.953 & 0.125 & 0.121 & 0.105 & 0.691 & 0.567 & 0.138 & 0.167 \\
\hline GRE9 & 0.687 & 0.090 & 0.001 & 0.004 & 0.413 & 0.524 & 0.324 & 0.431 \\
\hline GRE10 & 0.373 & 0.018 & 0.002 & 0.003 & 0.101 & 0.052 & 0.090 & 0.025 \\
\hline GRE11 & 0.928 & 0.541 & 0.036 & 0.152 & 0.427 & 0.504 & 0.323 & 0.252 \\
\hline GRE12 & 0.739 & 0.063 & 0.002 & 0.011 & 0.668 & 0.024 & 0.105 & 0.194 \\
\hline GRE13 & 0.054 & 0.005 & 0.000 & 0.017 & 0.008 & 0.322 & 0.029 & 0.047 \\
\hline GRE14 & 0.022 & 0.027 & 0.000 & 0.093 & 0.660 & 0.061 & 0.038 & 0.088 \\
\hline GRE15 & 0.015 & 0.001 & 0.000 & 0.000 & 0.240 & 0.001 & 0.007 & 0.022 \\
\hline GRE16 & 0.540 & 0.058 & 0.008 & 0.012 & 0.843 & 0.384 & 0.528 & 0.481 \\
\hline GRE17 & 0.834 & 0.042 & 0.024 & 0.024 & 0.281 & 0.299 & 0.241 & 0.166 \\
\hline GRE18 & 0.183 & 0.003 & 0.000 & 0.016 & 0.705 & 0.101 & 0.126 & 0.076 \\
\hline GRE19 & 0.765 & 0.011 & 0.015 & 0.123 & 0.011 & 0.007 & 0.087 & 0.102 \\
\hline GRE20 & 0.132 & 0.015 & 0.002 & 0.086 & 0.065 & 0.348 & 0.378 & 0.237 \\
\hline GRE21 & 0.950 & 0.918 & 0.053 & 0.029 & 0.980 & 0.511 & 0.619 & 0.711 \\
\hline GRE22 & 0.906 & 0.001 & 0.006 & 0.003 & 0.958 & 0.080 & 0.454 & 0.457 \\
\hline GRE23 & 0.769 & 0.010 & 0.003 & 0.000 & 0.086 & 0.163 & 0.038 & 0.034 \\
\hline GRE24 & 0.511 & 0.033 & 0.039 & 0.347 & 0.746 & 0.207 & 0.134 & 0.323 \\
\hline GRE25 & 0.997 & 0.021 & 0.002 & 0.004 & 0.000 & 0.020 & 0.067 & 0.000 \\
\hline GRE26 & 0.096 & 0.012 & 0.001 & 0.000 & 0.229 & 0.443 & 0.003 & 0.132 \\
\hline GRE27 & 0.608 & 0.001 & 0.002 & 0.002 & 0.019 & 0.154 & 0.015 & 0.033 \\
\hline GRE28 & 0.552 & 0.501 & 0.096 & 0.874 & 0.991 & 0.322 & 0.316 & 0.870 \\
\hline GRE29 & 0.240 & 0.010 & 0.001 & 0.006 & 0.417 & 0.147 & 0.390 & 0.018 \\
\hline GRE30 & 0.888 & 0.083 & 0.148 & 0.328 & 0.957 & 0.793 & 0.523 & 0.919 \\
\hline GRE31 & 0.188 & 0.027 & 0.044 & 0.159 & 0.565 & 0.265 & 0.028 & 0.075 \\
\hline GRE32 & 0.490 & 0.028 & 0.021 & 0.093 & 0.512 & 0.656 & 0.053 & 0.041 \\
\hline GRE33 & 0.898 & 0.176 & 0.059 & 0.010 & 0.951 & 0.869 & 0.505 & 0.591 \\
\hline mean & 0.540 & 0.114 & 0.026 & 0.080 & 0.521 & 0.287 & 0.219 & 0.259 \\
\hline
\end{tabular}


b) Eunicella cavolini

LAN NISB SAN SFV UST

\begin{tabular}{llllll}
\hline GAZ1 & 0.635 & 0.000 & 0.010 & 0.011 & 0.017
\end{tabular}

\begin{tabular}{llllllllll}
\hline GAZ2 & 0.015 & 0.000 & 0.000 & 0.000 & 0.003
\end{tabular}

\begin{tabular}{llllllll}
\hline GAZ3 & $\mathbf{0 . 9 9 9}$ & 0.001 & 0.371 & 0.260 & 0.004 \\
\hline
\end{tabular}

\begin{tabular}{llllll} 
GAZ4 & 0.606 & 0.000 & 0.000 & 0.027 & 0.000 \\
\hline
\end{tabular}

\begin{tabular}{lllllll}
\hline GAZ5 & $\mathbf{1 . 0 0 0}$ & 0.138 & 0.390 & 0.420 & 0.167 \\
\hline
\end{tabular}

\begin{tabular}{lllllll}
\hline GAZ6 & 0.921 & 0.000 & 0.013 & 0.016 & 0.061
\end{tabular}

\begin{tabular}{lllllll}
\hline GAZ7 & $\mathbf{0 . 9 9 4}$ & 0.456 & 0.480 & 0.605 & 0.016 \\
\hline
\end{tabular}

\begin{tabular}{llllll}
\hline GAZ8 & 0.834 & 0.000 & 0.079 & 0.283 & 0.005 \\
\hline
\end{tabular}

\begin{tabular}{llllll}
\hline GAZ9 & 0.927 & 0.061 & 0.337 & 0.181 & 0.013
\end{tabular}

\begin{tabular}{llllll}
\hline GAZ10 $0.017 \quad 0.000$ & 0.000 & 0.000 & 0.002
\end{tabular}

\begin{tabular}{llllllllll}
\hline GAZ11 & 0.665 & 0.009 & 0.028 & 0.059 & 0.095
\end{tabular}

\begin{tabular}{lllll}
\hline GAZ12 & $\mathbf{0 . 9 6 8} 0.000 \quad 0.017 \quad 0.382$ & 0.010
\end{tabular}

GAZ13 $0.3760 .000 \quad 0.0000 .0000 .000$

GAZ14 $0.5040 .000 \quad 0.000 \quad 0.000 \quad 0.000$

GAZ15 $0.4670 .000 \quad 0.0010 .000 \quad 0.003$

\begin{tabular}{llllllll}
\hline GAZ16 & 0.554 & 0.000 & 0.010 & 0.018 & 0.039
\end{tabular}

\begin{tabular}{llllll}
\hline GAZ17 & 0.979 & 0.005 & 0.701 & 0.287 & 0.173 \\
\hline
\end{tabular}

\begin{tabular}{lllllllllllllll}
\hline GAZ18 & 0.932 & 0.000 & 0.018 & 0.043 & 0.021
\end{tabular}

\begin{tabular}{llllll}
\hline GAZ19 0.450 & 0.000 & 0.000 & 0.005 & 0.000
\end{tabular}

\begin{tabular}{llllllll}
\hline GAZ20 & 0.131 & 0.000 & 0.003 & 0.001 & 0.005
\end{tabular}

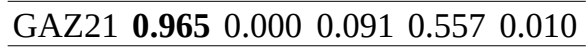

$\begin{array}{lllllll}\text { GAZ22 } & 0.507 & 0.000 & 0.000 & 0.006 & 0.145\end{array}$

\begin{tabular}{llllllll}
\hline GAZ23 & 0.116 & 0.000 & 0.000 & 0.000 & 0.000
\end{tabular}

\begin{tabular}{llllll}
\hline GAZ24 & 0.2530 .000 & 0.002 & 0.001 & 0.000
\end{tabular}

\begin{tabular}{llllll} 
GAZ25 & $\mathbf{0 . 9 8 8}$ & 0.001 & 0.050 & 0.782 & 0.013 \\
\hline
\end{tabular}

\begin{tabular}{lllllll}
\hline GAZ26 & 0.306 & 0.000 & 0.015 & 0.153 & 0.000
\end{tabular}

\begin{tabular}{lllllll}
\hline GAZ27 & $\mathbf{0 . 9 7 6}$ & 0.001 & 0.109 & 0.128 & 0.038
\end{tabular}

\begin{tabular}{lllllllllllllllllll}
\hline GAZ28 & 0.820 & 0.063 & 0.041 & 0.150 & 0.058
\end{tabular}

GAZ29 $0.3030 .000 \quad 0.000 \quad 0.000 \quad 0.000$

\begin{tabular}{lllllll}
\hline GAZ30 0.807 & 0.000 & 0.050 & 0.114 & 0.008
\end{tabular}

\begin{tabular}{lllllllll}
\hline GAZ31 & 0.746 & 0.023 & 0.329 & 0.370 & 0.005
\end{tabular}

GAZ32 0.7070 .0000 .0010 .0010 .001

\begin{tabular}{llllll}
\hline mean & 0.640 & 0.024 & 0.098 & 0.152 & 0.029 \\
\hline
\end{tabular} 